\title{
Antibacterial properties of films of cellulose composites with silver nanoparticles and antibiotics
}

\author{
Tatiana G. Volova ${ }^{a, b}$, Anna A. Shumilova ${ }^{a}$, Ivan P. Shidlovskiy ${ }^{a}$, \\ Elena D. Nikolaeva ${ }^{\mathrm{b}}$, Alexey G.Sukovatiy ${ }^{\mathrm{b}}$, Alexander D. Vasiliev ${ }^{\mathrm{a}, \mathrm{c}}$, Ekaterina I. Shishatskaya ${ }^{\mathrm{a}, \mathrm{b}}$ \\ ${ }^{a}$ Siberian Federal University, 79 Svobodnyi Av., Krasnoyarsk 660041, Russia \\ ${ }^{b}$ Institute of Biophysics SB RAS, Federal Research Center "Krasnoyarsk Science Center SB RAS”, 50/50 \\ Akademgorodok, Krasnoyarsk 660036, Russia \\ ${ }^{c}$ Institute of Physics. L.V. Kirensk SB RAS, Federal Research Center “Krasnoyarsk Science Center SB RAS”,43/50 \\ Akademgorodok, Krasnoyarsk, 660036, Russia
}

\begin{abstract}
The present study describes production of bacterial cellulose composites with silver nanoparticles and antibiotics and compares their properties. Bacterial cellulose (BC) composites synthesized in the culture of the strain of acetic acid bacterium Komagataeibacter xylinus VKPM B-12068 with silver nanoparticles, BC/AgNps, were produced hydrothermally, under different $\mathrm{AgNO}_{3}$ concentrations $(0.0001,0.001$, and $0.01 \mathrm{M})$ in the reaction medium. The presence of silver in the $\mathrm{BC} / \mathrm{AgNp}$ composites was confirmed by elemental analysis conducted using scanning electron microscopy with a system of X-ray spectral analysis. Analysis showed that the average atomic number of silver particles in composite samples depended on the concentration of $\mathrm{AgNO}_{3}:$ as $\mathrm{AgNO}_{3}$ concentration in the reaction solution was increased, silver content in the composites increased from 0.044 to $0.37 \mathrm{mg} / \mathrm{cm}^{2}$. BC composites with amikacin and ceftriaxone were prepared by immersing dry BC films in solutions containing different concentrations of the antibiotics. The surface structure and properties and physicochemical and mechanical characteristics of composites were investigated using SEM, DSC, X-ray analysis, the system for measuring water contact angles, and electromechanical tensile testing machine. The disk-diffusion method and the shake-flask culture method used in this study showed that all experimental composites had pronounced antibacterial activity against $E$. coli, Ps. eruginosa, K. pneumoniae, and St. aureus, and the BC/antibiotic composites were more active than $\mathrm{BC} / \mathrm{AgNp}$ ones; $S$. aureus was the most susceptible to the effect of BC composites. No potential cytotoxicity was detected in any of the $\mathrm{BC} / \mathrm{AgNp}$ composites in the $\mathrm{NIH} 3 \mathrm{~T} 3$ mouse fibroblast cell culture, in contrast to the $\mathrm{BC} /$ antibiotic composites. These results suggest that $\mathrm{BC}$ composites constructed in the present study hold promise as dressings for managing wounds, including contaminated ones.
\end{abstract} activity

Key words: bacterial cellulose, composites, silver nanoparticles, antibiotics, properties, antibacterial

\section{Introduction}

Bacterial cellulose (BC) - a biopolymer synthesized by microorganisms - is a promising material for biomedical application. The chemical structure of $\mathrm{BC}$ is similar to that of plant-derived cellulose, but $\mathrm{BC}$ has unique physical, mechanical, and chemical properties. This material shows high biocompatibility, without being cytotoxic or causing any allergic reactions. Studies of BC suggest that this natural polymer can be useful for cellular and tissue engineering as material for constructing scaffolds and for reconstructive surgery as material for skin defect reconstruction and as a matrix for drug delivery [1;2]. Physical and mechanical properties of BC can be enhanced by preparing $\mathrm{BC}$ composites with various materials: chitosan [3], collagen [4], sodium alginate, gelatin, polyethylene glycol [5].

$\mathrm{BC}$ is not inherently antibacterial, but BC composites with chitosan and alginate inhibit growth of pathogenic microorganisms such as E.coli, Candida albicans, and Staphylococcus aureus [3; 6; 7]. Therefore, BC composite films can be considered for treating contaminated wounds. BS can be hybridized with metallic silver particles to produce an antibacterial and wound-healing formulation. Metallic silver and compounds thereof have a strong bactericidal effect, inhibiting development of a wide range of pathogenic microorganisms. Silver ions react with cell membrane protein thiol groups, affecting bacterial respiration and transport of substances through the cell membrane [8].

Production of BC composites with silver nanoparticles has been extensively discussed in the literature. Various approaches have been proposed of the in situ generation of $\mathrm{Ag}$ or $\mathrm{Cu}$ and other metals in cellulose matrix and cotton fabrics, by using different reducing agents and by hydrothermal methods, which are simpler to use and ecofriendly.

Composites of silver nanoparticles and bacterial cellulose with high antimicrobial activity were prepared using Tollens' reaction [9] with silver reduced by polydopamine, which had been used as a medium for immersion of homogenized cellulose [10]. Other authors [11] used a more complex approach to producing silver nanoparticles: homogenized cellulose was first oxidized using 2,2,6,6-tetramethylpiperidine-1-oxyl (TEMPO), which created carboxyl groups on the surface, and then $\mathrm{Na}^{+}-\mathrm{Ag}^{+}$exchange reaction was performed; the ions were reduced using $\mathrm{NaBH}_{4}$ or sodium citrate. The silver particles produced by this method were of different sizes and effective against Escherichia coli and Staphylococcus aureus. 
Different modifications of hydrothermal methods for production of nanosilver and other metals involve the use of bacterial cellulose and natural plant-derived agents as reductants. G. Yang et al. [12] used a hydrothermal method with cellulose employed as a reducing and stabilizing agent. By optimizing reaction parameters, the authors obtained narrow distribution of Ag particles, thus achieving an effective and durable antibacterial action. Composites of cellulose with silver sulfadiazine dispersed to nanosize were used as antimicrobial wound dressing [13], which facilitated the healing of model burns in rats. J. Wu et al. [14] reported a study in which model burns were treated with composites prepared by reducing Ag+ on the surface of cellulose fibers. The composites suppressed wound microflora and favored fibroblast attachment. Silver nanoparticles were produced in situ in cotton fabrics by the hydrothermal method at $80^{\circ} \mathrm{C}$ [15]. The composites showed good antibacterial activity against Gramnegative and Gram-positive bacteria. A similar method was used to prepare a cotton composite with copper nanoparticles [16]. Cotton nanocomposite fabrics exhibited good antibacterial activity and were effective against both Gram-positive and Gram-negative bacteria. Hence, they can be used in medical applications: as wound dressings, surgical aprons, materials for hospital beds, etc. In another study [17], silver nanoparticles were produced in situ in cellulose matrix using Ocimum leaf extract as a reducing agent. Composite films showed good antibacterial activity and, thus, can be used for packaging and medical purposes. P. Sivaranjana et al. (2017) [18] reported producing cellulose nanocomposite films with in situ generated silver nanoparticles using Cassia alata leaf extract as a reducing agent. The nanocomposite cellulose/AgNP films had good tensile properties and showed antibacterial activity; therefore, they can be considered for medical applications as dressing materials.

A number of studies report successful uses of plant extracts as reducing agents for silver ions. In a study by L. Muthulakshmi et al. [19], copper nanoparticles (CuNPs) were generated in situ inside cellulose matrix using Terminalia catappa leaf extract as a reducing agent, and their properties were investigated. The composite films possessed sufficient tensile strength, and, thus, they can replace polymer packaging materials like polyethylene. Further, the cellulose/CuNP composite films exhibited good antibacterial activity against E.coli.

In another work [20], cellulose gel films with nanosilver were produced using a precooled mixture of 8 wt \% lithium hydroxide and $15 \mathrm{wt} . \%$ urea as a solvent and ethyl alcohol as a nonsolvent, with the Terminus cattapa leaf extract used as a reducing agent. Composite cellulose/AgNP films showed good antibacterial activity against $E$. coli and Bacillus sp. Hydrothermal synthesis was used to produce nanoparticles of other metals too. For instance, polyhedron-shaped hematite (a-Fe2O3) nanoparticles were successfully synthesized via a facile hydrothermal method by mixing $\mathrm{FeCl} 3$ and $\mathrm{NH}_{4} \mathrm{OH}$ at high temperature [21].

Besides BC, recent publications demonstrated that cellulose nanocrystals and hydrogels could also be used as reductant and support for the synthesis of AgNPs. For example, Rui Xiong et al. [22] demonstrated a facile and environmentally friendly approach to prepare $\mathrm{Fe}_{3} \mathrm{O}_{4} / \mathrm{Ag} /$ nanofibrillated cellulose (NFC) nanocomposites, which enables tunability from highly porous, flexible aerogels to solid and stiff films. NFC acts as a biocompatible support for the magnetic silver nanoparticles and a reducing agent for the silver ions. The $\mathrm{Fe}_{3} \mathrm{O}_{4} / \mathrm{Ag} / \mathrm{NFC}$ nanocomposite aerogel exhibited excellent catalytic properties for the reduction of 4-nitrophenol, and showed high antibacterial activity against the model microbe $S$. aureus.

Several studies showed advantages of using cellulose crystals as a reductant for producing nanosilver. Rui Xiong et al. [23] described production of well dispersed and stable silver nanostructures using cellulose nanocrystals without employing other reductants or dispersing agents. Moreover, the authors showed that morphology of silver nanostructures could be adjusted by changing $\mathrm{AgNO}_{3}$ concentration and producing silver shaped as nanospheres or dendrites with different antibacterial activity (more pronounced in dendritic silver) against Escherichia coli and Staphylococcus aureus. Successful use of cellulose crystals for producing hybrid silver/biodegradable polymer nanocomposites as potential food packaging was reported by $\mathrm{Yu}$ et al. The authors produced nanocomposites consisting of biodegradable nanohydrates poly(3-hydroxybutyrate-co-3-hydroxyvalerate) (PHBV) and cellulose/silver nanocrystals (CNC-Ag) with improved thermal, mechanical, and antibacterial properties [24]. The authors found that homogeneously dispersed CNC-Ag could serve as a factor improving the properties of the pristine polymer. In another study [25], the authors described fabrication of multifunctional cellulose nanocrystals/poly(lactic acid) nanocomposites with silver nanoparticles by spraying method. Deposited silver (Ag) nanoparticles and CNF effectively reinforced mechanical properties and antibacterial activity of polylactide as well as water vapor permeability of the composite film, which was important for the packaging material. In a study by W. $\mathrm{Xu}$ et al. [26], cellulose nanocrystals (CNCs) produced by hydrolysis of sulfuric acid were dispersed in polycarbonate (PC) in organic solution to prepare a composite. Due to the good dispersion of nanofillers in polymeric matrix, strong hydrogen bonds were formed between carbonyl groups of polycarbonate and hydroxyl groups of cellulose, which caused improvement of thermal and mechanical properties of the composite films.

A novel and straightforward synthetic strategy was developed to prepare silver nanoparticles-doped cellulose microgels (AgNPs/CMG) nanohybrids at room temperature [27]. The as-prepared AgNPs/CMG nanohybrids exhibited excellent catalytic performance in reduction of 4-nitrophenol and organic dyes. The simplicity, sustainability, and straightforwardness of this approach to prepare a highly efficient catalyst and functional membrane open up new possibilities for large-scale production and application of bioresources/noble metal nanohybrids in various fields.

Another approach to imparting antibacterial activity against pathogenic microflora to $\mathrm{BC}$ is to prepare $\mathrm{BC}$ composites with antibiotics. As a potential wound dressing for treating acute traumas, freeze-dried BC film was loaded with benzalkonium chloride - an antimicrobial agent of cationic surfactant type. Antimicrobial activity of the 
composite was observed for $24 \mathrm{~h}$ against Staphylococcus aureus and Bacillus subtilis, which were the major bacteria in the contaminated wound [28]. Composites of bacterial cellulose with tetracycline hydrochloride, BC-TCH, were produced and characterized by other authors [29; 30]. The composites exhibited excellent antibacterial activity and good biocompatibility and enabled controlled release of the antibiotic.

Analysis of the literature suggests that production of nanocomposites based on bacterial cellulose is a promising and important subject of research. However, most of the studies describe production of BC composites with nanosilver and characterize them as dependent on the technique of production and ratios of components in the composites. Much less consideration has been given to the properties of BC composites with antibiotics.

Therefore, the purpose of this study was to prepare bacterial cellulose composites with silver nanoparticles and antibiotics and to compare their properties and antibacterial activity.

\section{Experimental}

\subsection{Materials}

Bacterial cellulose films were synthesized in the Komagataei bacterxylinus B-12068 culture. The strain was isolated from the fermented tea (kombucha) Medusomyces gisevii J. Lindauon Hestrin-Schramm (HS) medium [31]. The strain was identified based on its morphological, biochemical, genetic, and growth parameters. The strain Komagataeibacter xylinus was deposited in the Russian National Collection of Industrial Microorganisms (VKPM) with registration number VKPM B-12068 and patented [32] The collection culture of K. xylinus B-12068 was maintained on the Hestrin-Schramm (HS) agar medium. The standard HS medium contained (\% w/v): glucose -2 , peptone -0.5 , yeast extract $-0.5, \mathrm{Na}_{2} \mathrm{HPO}_{4}-0.27$, and citric acid -0.115 . The pre-culture was performed on the HS agar. Then, the colonies were transferred into the flask containing liquid HS medium and cultivated for 7 days at a temperature of $30^{\circ} \mathrm{C}$ under static conditions as described elsewhere [33]. To remove remnants of bacterial cells and components of culture medium, BC films were treated with $1.0 \mathrm{M} \mathrm{NaOH}$ at $70{ }^{\circ} \mathrm{C}$, followed by washing in deionized water. The synthesized cellulose was separated from the culture fluid. Then, BC films were placed in a $0.5 \%$ solution of hydrochloric acid for $24 \mathrm{~h}$ for neutralization and, afterwards, rinsed in distilled water until $\mathrm{pH} 7$. The BC films were stored in sterile solution or air dried until they reached a stable weight.

$\mathrm{BC}$ composites with silver nanoparticles and antibiotics were prepared using $\mathrm{AgNO}_{3}$ (Uralkhiminvest, Russia) and ceftriaxone and amikacin (Sintez, Russia).

\subsection{Production of BC composites with silver nanoparticles, BC/AgNps}

BC composites with silver nanoparticles, BC/AgNps, were produced by a hydrothermal method without utilizing any catalysts, using the disks of BC layer as a reducing and stabilizing agent [34]. Purified raw BC films were cut into disks $1 \mathrm{~cm}$ in diameter, placed in flasks with $0.0001,0.001$, and $0.01 \mathrm{M}$ of $\mathrm{AgNO}_{3}$, and heated for 60 minutes at a temperature of $90{ }^{\circ} \mathrm{C}$. Composite $\mathrm{BC}$ films with silver nanoparticles were lyophilized at a temperature of $-40{ }^{\circ} \mathrm{C}$ and pressure of 0.12 mbar for 24 hours in a vacuum drying unit ALPHA 1-2/LD (Martin Christ GmbH, Germany) or kept at room temperature in a laminar flow cabinet for $24 \mathrm{~h}$. The parameters of the produced silver nanoparticles were investigated with a Zetasizer Nano ZS particle analyzer (Malvern, U.K.), employing dynamic light scattering, electrophoresis, and laser Doppler anemometry.

\subsection{Production of BC composites with antibiotics}

In order to impart bactericidal properties to cellulose, we prepared BC composites with antibacterial drugs. We used amikacin (Sintez, Russia) and ceftriaxone (Sintez, Russia). The dried BC films were immersed in solutions of antibiotics of different concentrations. After $24 \mathrm{~h}$ of immersion, the films were removed from the antibiotic solutions, washed in distilled water, and dried at room temperature. Then, the films were die-cut into disks $1 \mathrm{~cm}$ in diameter.

\subsection{A study of structure and physical and mechanical properties of BC composites}

The thickness of BC films was measured with a LEGIONER EDM-25-0.001 electronic digital micrometer (Legioner, China); accuracy of measurement was $1 \mu \mathrm{m}$. Surface properties of the BC films and membranes were examined using a DSA-25E drop shape analyzer (Krüss. Germany) and software DSA-4 for Windows. Drops of water and diiodomethane, $1.5 \mu \mathrm{l}$ each, were alternately placed on the sample surface with microsyringes, and moments of interaction between each liquid and sample surface were video recorded. Contact angles of these liquids were measured by processing the frame of a stabilized drop in a semiautomatic mode, by the "Circle" method, which is embedded in the software package. The results of measurements were used to calculate surface free energy and its dispersive and polar components $(\mathrm{mN} / \mathrm{m})$ by the Owens, Wendt, Rabel and Kaelble method [35; 36]. A minimum of six measurements were taken for each surface; means and standard deviations were calculated. 
The surface microstructure of the BC films was analyzed using scanning electron microscopy (S 5500, Hitachi, Japan). Prior to the analysis, the films were freeze-dried in an ALPHA 1-2/LD freeze dryer (Martin Christ $\mathrm{GmbH}$, Germany) for $24 \mathrm{~h}$. Samples $(5 \times 5 \mathrm{~mm})$ were placed onto the sample stage and sputter-coated with gold, using an Emitech K575X sputter coater $(10 \mathrm{~mA}, 2 \times 40 \mathrm{~s})$. Fiber diameters were measured by analyzing SEM images with image analysis program Image Processing and Data Analysis in Java (ImageJ). The diameters of 50 individual ultrafine fibers were then measured in each SEM micrograph. Diameters were analyzed in 10 fields of SEM images in triplicate.

The elemental composition of the BC composites was examined using scanning electron microscopy (a TM-3000 Hitachi microscope with the QUANTAX 70 program).

Thermal analysis of samples was performed using a DSC-1 differential scanning calorimeter (METTLER TOLEDO, Switzerland). Powdered samples (4.0 $\pm 0.2 \mathrm{mg}$ each) were placed into the aluminum crucible and compressed prior to measurement. Every sample was measured at least 3 times. Samples were preheated to $60^{\circ} \mathrm{C}$ and cooled to $25^{\circ} \mathrm{C}$. The samples were heated to temperatures from $25^{\circ} \mathrm{C}$ to $300^{\circ} \mathrm{C}$, at $5^{\circ} \mathrm{C} \times \min ^{-1}$ (measurement precision $\left.1.5^{\circ} \mathrm{C}\right)$; melting point $\left(\mathrm{T}_{\mathrm{m}}\right)$ and thermal decomposition temperature $\left(\mathrm{T}_{\mathrm{d}}\right)$ were determined from exothermal peaks in thermograms. The thermograms were analyzed using the STARe v11.0 software.

$\mathrm{X}$-Ray structure analysis and determination of crystallinity of the BC composites were performed employing a D8 ADVANCE X-Ray powder diffractometer equipped with a VANTEC fast linear detector, using CuKa radiation (Bruker, AXS, Germany). In order to determine the crystallinity $\left(\mathrm{C}_{\mathrm{x}}\right)$ of $\mathrm{BC}$, the spectra were collected from a $\mathrm{V}_{\text {antec }}$ high-speed detector, with exposure time of 3000 . The detector was operated at $40 \mathrm{kV}$ and 40 $\mathrm{mA}$.

Mechanical properties of the BC composites were investigated using an electromechanical tensile testing machine Instron 5565 (U.K.). Samples $75 \mathrm{~mm}$ long, $12 \mathrm{~mm}$ wide were prepared for studying physical and mechanical properties of the films.

At least five samples were tested for each type of films. Measurements were conducted at ambient temperature; the clamping length of the samples was $50 \mathrm{~mm}$. The speed of the crosshead was $3 \mathrm{~mm} / \mathrm{min}$ at ambient temperature. Young's modulus $(\mathrm{E}, \mathrm{MPa})$, tensile strength $(\sigma, \mathrm{MPa})$ and elongation at break $(\varepsilon, \%)$ were automatically calculated by the Instron software (Bluehill 2, Elancourt, France). To obtain Young's modulus, the software calculated the slope of each stress-strain curve in its elastic deformation region. Measurement error did not exceed $10 \%$.

BC films were sterilized with $\mathrm{H}_{2} \mathrm{O}_{2}$ plasma in a Sterrad NX medical sterilizer (Johnson \& Johnson, U.S.) and investigated in cell culture assays.

\subsection{Protein adsorption test}

To estimate the antiadhesive effect of $\mathrm{BC} / \mathrm{AgNp}$ and $\mathrm{BC} /$ antibiotic films towards protein, protein adsorption test was performed using bovine serum albumin (BSA) (“Amresco", U.S.). The BC composites were incubated in $5 \mathrm{ml}$ of the PBS solution with albumin concentration of $1 \mathrm{mg} / \mathrm{ml}$ at $37^{\circ} \mathrm{C}$ for $24 \mathrm{~h}$. Then, the BC samples were removed, and the remaining protein solution was analyzed. To determine protein concentration, alkaline copper solution and Folin's reagent were added to $1 \mathrm{ml}$ of the protein solution. After 30 min exposure, which was necessary for color to develop, optical density was measured using a spectrophotometer (Bio-Rad LABORATORIES Inc., U.S.) at a wavelength of $570 \mathrm{~nm}$, and residual protein content in the solution was calculated from the standard curve.

\subsection{In vitro release of nanosilver and antibiotics from BC composites}

Sterile composite samples were exposed to phosphate-buffered saline (PBS) to investigate release of silver and antibiotics. Under aseptic conditions, the samples were placed into vials, each containing $50 \mathrm{ml} \mathrm{saline} \mathrm{at} \mathrm{pH}=$ 6.0 for silver and $\mathrm{pH}=7$ for antibiotics. The vials were incubated in a thermostat for $72 \mathrm{~h}$ at a temperature of $37^{\circ} \mathrm{C}$. The experiment was done with BCAgNP samples $1 \mathrm{~cm}$ in diameter prepared at AgNO3 concentrations of 0.0001 , 0.001 , and $0.01 \mathrm{M}$ and $\mathrm{BC}$ samples with different percentages of antibiotics: amikacin (between 0.2 and $1 \%$ ) and ceftriaxone (between 0.2 and $6 \%$ ).

To estimate release kinetics, samples were periodically taken out of the saline, and concentration of nanosilver was determined using atomic absorption spectrophotometry (AAS), and concentrations of antibiotics were measured using a Cary $60 \mathrm{UV}$-Vis spectrophotometer (Agilent Technologies): amikacin at a wavelength of $210 \mathrm{~nm}$ and ceftriaxone at $304 \mathrm{~nm}$.

\subsection{In vitro antibacterial tests}

The direct inhibitory effect of $\mathrm{BC} / \mathrm{AgNp}$ and $\mathrm{BC} /$ antibiotic composites was tested on cultures of reference strains - Escherichia coli ATCC 25922, Pseudomonas eruginosa ATCC 27853, Klebsiella pneumoniae 204, and Staphylococcus aureus ATCC 25923, using disk-diffusion method in agar (20 ml) on Petri dishes. The dishes were allowed to stay at room temperature to solidify. The bacterial suspension was standard inoculum whose 
density corresponded to the $0.5 \mathrm{McF}$ arland standard, which contained approximately $1.5 \times 10^{8} \mathrm{CFU} / \mathrm{ml}$. The Petri dishes were placed upside-down into an incubator and kept at a constant temperature of $35^{\circ} \mathrm{C}$ for $18-24 \mathrm{~h}$ (depending on the microorganism tested). The diameter of the growth retardation zones and the distance from the edge of the film to the end of the absence zone were measured by photographs of dishes, using the Image J. program. The results were processed using the Microsoft Excel application package. The arithmetic mean and standard deviation were calculated.

Another test was conducted by cultivation of microorganisms using the shake-flask culture method, with BC/AgNp and BC/antibiotic films placed into the culture medium of Escherichia coli and Staphylococcus aureus. $\mathrm{BC}$ composite disks $10 \mathrm{~mm}$ in diameter $(\mathrm{n}=27)$ were placed in test tubes, and $5 \mathrm{ml}$ of microbial suspension of $E$. coli $\left(0.6 \times 10^{8} \mathrm{CFU} / \mathrm{ml}\right)$ or St. aureus $\left(0.6 \times 10^{8} \mathrm{CFU} / \mathrm{ml}\right)$ prepared beforehand was added to each test tube. These tubes were shaken at $250 \mathrm{rpm}$ in incubators at a constant temperature of $37^{\circ} \mathrm{C}$ for $24 \mathrm{~h}$. Then, the samples were read in a KFK-2 photocolorimeter ("ZOMZ", Russia) at the absorbance at $600 \mathrm{~nm}$ to measure the densities of the bacterial cultures. The cells were counted using the standard curve constructed by the Breed method, relative to the initial values of the optical densities of the cultures.

\subsection{Cytotoxicity assays}

The ability of BC films to facilitate cell attachment was studied using NIH 3T3 mouse fibroblast cells. The films were placed into 24-well cell culture plates (Greiner Bio-One, U.S.) and sterilized in a Sterrad NX medical sterilizer (Johnson \& Johnson, U.S.). Cells were seeded at $1 \times 10^{3}$ cells $/ \mathrm{ml}$ per well. Cells were cultured in DMEM medium supplemented with $10 \%$ fetal bovine serum and a solution of antibiotics (streptomycin $100 \mu \mathrm{g} / \mathrm{ml}$, penicillin $100 \mathrm{IU} / \mathrm{ml}$ ) (Sigma) in a $\mathrm{CO}_{2}$ incubator with $\mathrm{CO}_{2}$ level maintained at $5 \%$, at a temperature of $37{ }^{\circ} \mathrm{C}$. The medium was replaced every three days. The number of cells attached to the film surface was determined using DAPI.

Cell viability was evaluated using MTT assay at Day 7 after cell seeding onto films. Reagents were purchased from Sigma-Aldrich. A 5\% MTT solution $(50 \mu \mathrm{l})$ and complete nutrient medium $(950 \mu 1)$ were added to each well of the culture plate. After $3.5 \mathrm{~h}$ incubation, the medium and MTT were replaced by DMSO to dissolve MTT-formazan crystals. After $30 \mathrm{~min}$, the supernatant was transferred to the 96 -well plate, and optical density of the samples was measured at wavelength $540 \mathrm{~nm}$, using a Bio-Rad 680 microplate reader (Bio-Rad LABORATORIES Inc., U.S.). Measurements were performed in triplicate. The number of viable cells was determined from the standard curve.

\subsection{Statistics}

Statistical analysis of the results was performed by conventional methods, using the standard software package of Microsoft Excel. Arithmetic means and standard deviations were found. The statistical significance of results was determined using Student's test (significance level: $\mathrm{P} \leq 0.05$ ). Statistical analysis of surface properties of the samples was performed by using embedded methods of the DSA-4 software.

\section{Results and discussion}

\subsection{Production and properties of $B C$}

The dried BC films synthesized in the Komagataeibacter xylinus B-12068 culture had similar thickness $(1.8 \pm 0.2 \mathrm{~mm})$ and density $\left(0.15 \pm 0.01 \mathrm{~cm}^{3}\right)$ while their surface properties differed considerably, as determined by water contact angle, which varied between $36^{\circ}$ and $57^{\circ}$. The ultrastructure and size of fibrils in $\mathrm{BC}$ is a critical factor that determines the unique properties of bacterial cellulose films. SEM images of the microstructure of BC films show that BC films were layered nets of different densities composed of randomly oriented microfibrils (Fig. 1). Whatever drying method was used, the average diameter of BC film microfibrils was $110 \mathrm{~nm}$, the smallest and the largest diameters being $52 \mathrm{~nm}$ and $173 \mathrm{~nm}$, respectively. However, in freeze-dried films, fibrils were positioned more loosely, and the distance between them was 2.5-3.0 times greater than in the films dried at room temperature, reaching about $1.6 \mu \mathrm{m}$. 

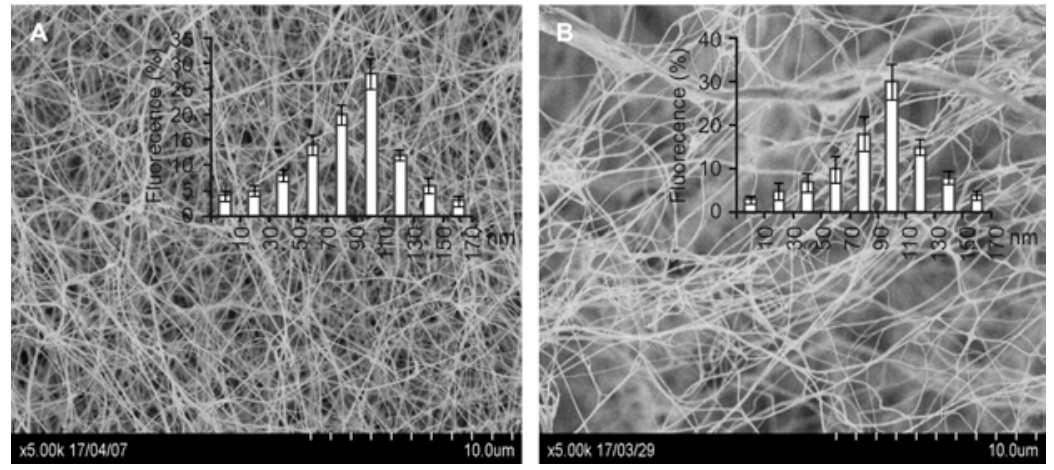

Fig. 1. SEM of pristine BC films and size distribution of the diameters of the fibers in the films dried at room temperature $(\mathrm{A})$ and freeze-dried ones $(\mathrm{B}) . \mathrm{Bar}=10 \mu \mathrm{m}$

\subsection{Production and properties of BC composites with silver nanoparticles, BC/AgNps}

During hydrothermal synthesis of silver nanoparticles, variations in $\mathrm{AgNO}_{3}$ concentration in the reaction medium at $90^{\circ} \mathrm{C}$ changed the number of the nanoparticles synthesized (Fig. 2A) without considerably influencing their size (Fig. 2B). For instance, the average sizes of $\mathrm{Ag}$ nanoparticles at $\mathrm{AgNO}_{3}$ concentrations of 0.0001, 0.001, and $0.01 \mathrm{M}$ were 13,23 , and $12 \mathrm{~nm}$, respectively.
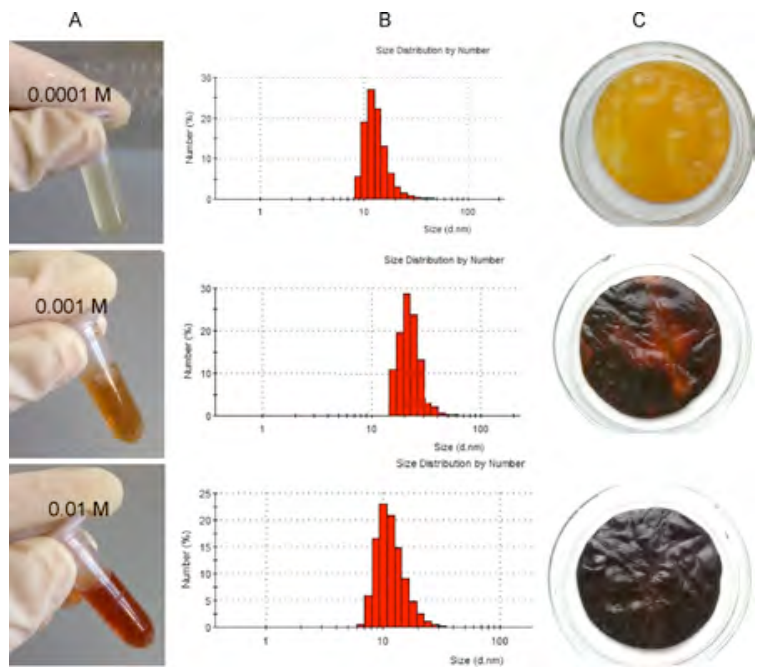

Fig. 2. The effect of $\mathrm{AgNO}_{3}$ concentration on production of $\mathrm{BC}$ composites with silver nanoparticles, BC/AgNps: A - reaction medium; B - size distribution of Ag nanoparticles; $\mathrm{C}$ - a photograph of composite films

The increase in the number of silver nanoparticles in BC films is illustrated by Figure 2C. That was confirmed by quantitative elemental analysis (Fig. 3 and Table 1).

Table 1 - The influence of conditions of the system on the elemental composition of BC/AgNps

\begin{tabular}{|c|c|c|c|c|}
\hline \multirow{2}{*}{ Samples } & \multicolumn{3}{|c|}{ Average atomic number (wt.\%) } & \multirow{2}{*}{$\begin{array}{c}\text { Ag content } \\
\left(\mathrm{mg}^{2} / \mathrm{cm}^{2}\right)\end{array}$} \\
\cline { 2 - 4 } & $\mathrm{O}$ & $\mathrm{C}$ & $\mathrm{Ag}$ & \\
\hline BC film & 59.8 & 40.1 & - & 0,044 \\
\hline $0.0001 \mathrm{M}$ & Influence of $\mathrm{AgNO}_{3}$ concentration at $90^{\circ} \mathrm{C}:$ & 1.08 & 0.16 \\
\hline $0.001 \mathrm{M}$ & 53.03 & 45.9 & 4.10 & 0.37 \\
\hline $0.01 \mathrm{M}$ & 54.2 & 41.7 & 9.1 & 0.1 \\
\hline
\end{tabular}

SEM images show that as $\mathrm{AgNO}_{3}$ concentration of the reaction medium was increased, the number of silver nanoparticles adhering to BC fibrils and between them increased too (Fig. 3). Ag nanoparticles showed different aggregation behavior in freeze-dried $\mathrm{BC}$ films compared to the films dried at room temperature. On the films dried at room temperature, the size of Ag particles was 25-60 nm, the size of their aggregates was $85-350 \mathrm{~nm}$, and the number of aggregates reached 15 per $1 \mu \mathrm{m}^{2}$. On freeze-dried films, particle aggregates were larger, between 350 and $780 \mathrm{~nm}$, and their number reached 19 per $1 \mu \mathrm{m}^{2}$. 

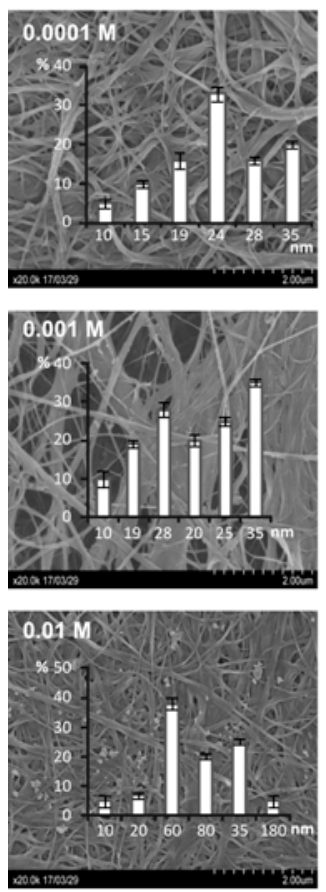
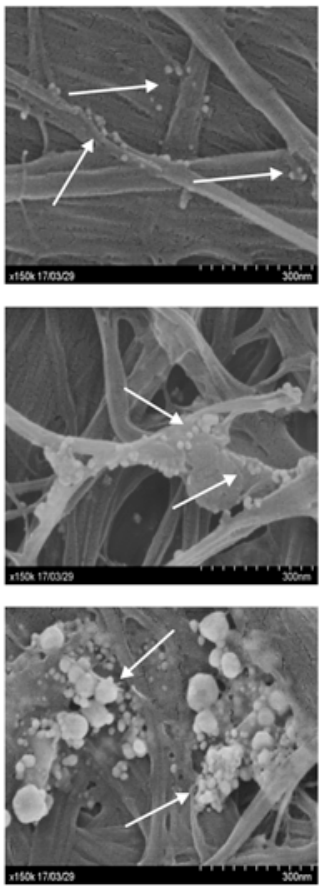
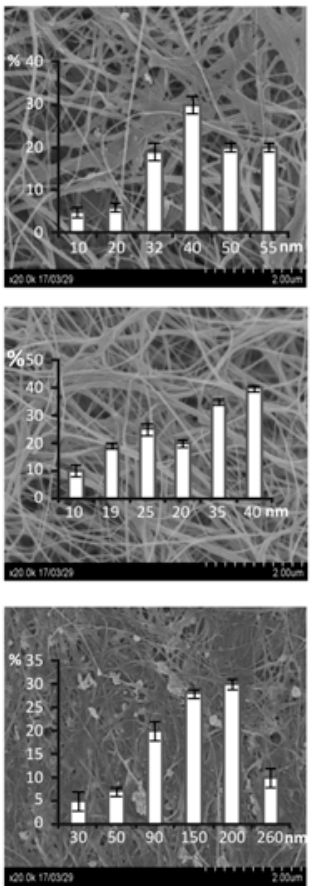
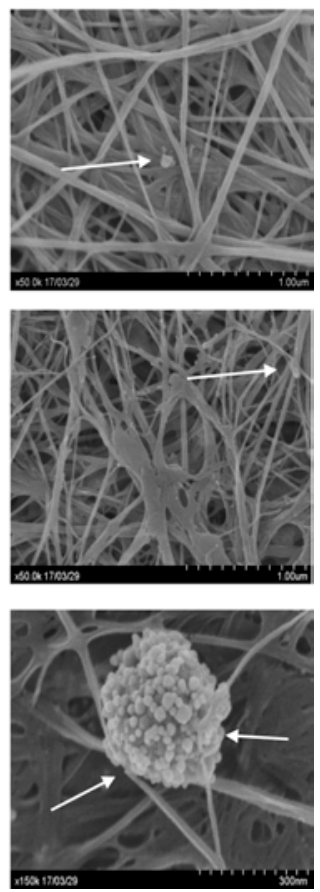

Fig. 3. SEM images of the films of BC composites with silver nanoparticles, BC/AgNps, and size distribution of silver nanoparticles in the films produced under different $\mathrm{AgNO}_{3}$ concentrations in the medium: films dried at room temperature (A) and freeze-dried films (B). Arrows denote aggregates of Ag nanoparticles. Bars = 200 and $300 \mu \mathrm{m}$

The presence of silver in the BC/AgNps was confirmed by elemental analysis performed using scanning electron microscopy with a system of X-ray spectral analysis (Table 1). Analysis showed that the average atomic number of silver particles in composite samples depended on the concentration of $\mathrm{AgNO}_{3} ;$ as $\mathrm{AgNO}_{3}$ concentration in the reaction solution was increased from 0.0001 to $0.01 \mathrm{M}$, silver content in the composites increased from 0.044 to $0.37 \mathrm{mg} / \mathrm{cm}^{2}$. Analysis of our results and the literature data shows that the main factors determining the structure of $\mathrm{BC} / \mathrm{AgNp}$ composites are the size of nanoparticles, Ag content of the BC composites, method employed to produce silver nanoparticles, and technique used to incorporate Ag nanoparticles into BC films. Silver concentration in $\mathrm{BC}$ films, silver nanoparticle size, and Ag particle aggregation between cellulose microfibrils obtained in this study by using hydrothermal synthesis are comparable with the data reported by G. Yang et al. [34] (the size of silver particles of 14-22 nm, silver content reaching $2.31 \% \mathrm{w} / \mathrm{w}$ ) and W. Shao et al. [29] (the size of particles of between 20 and $100 \mathrm{~nm}$ ). When silver nanoparticles were produced using reducing agents in the reaction medium (sodium citrate, sodium borohydride, UV radiation, triethanolamine, hydrazine, hydroxylamine, etc.), researchers $[10 ; 37-39]$ noted different sizes of Ag nanoparticles $(8-10 \mathrm{~nm})$ and their uniform distribution over the surface and between the fibrils of BC. Possible structural changes in the composites were determined by X-ray diffraction analysis and differential scanning calorimetry (Fig 4.) The degree of crystallinity $\left(\mathrm{C}_{\mathrm{x}}\right)$ of $\mathrm{BC}$ varied considerably depending on the carbon source used, the mode of cultivation of the strain, and the structure and arrangement of the microfibrils. Samples of pristine BC synthesized by the strain K. xylinus B-12068 differed substantially in their degrees of crystallinity depending on the carbon source used. The $\mathrm{C}_{\mathrm{x}}$ of the samples synthesized on the HS medium with galactose was $45 \%$, and the $C_{x}$ of the samples synthesized on the medium with glucose and sucrose was 63$68 \%$; the samples synthesized in the medium with the initial $\mathrm{pH}$ of 3.6 in the presence of citrate or acetate showed the highest $\mathrm{C}_{\mathrm{x}}(85-89 \%)$. Figure $4 \mathrm{a}$ shows results of $\mathrm{X}$-Ray and diffraction indices of $\mathrm{BC}$ composites with nanosilver, indicating the main reflexes corresponding to crystalline cellulose and silver. 


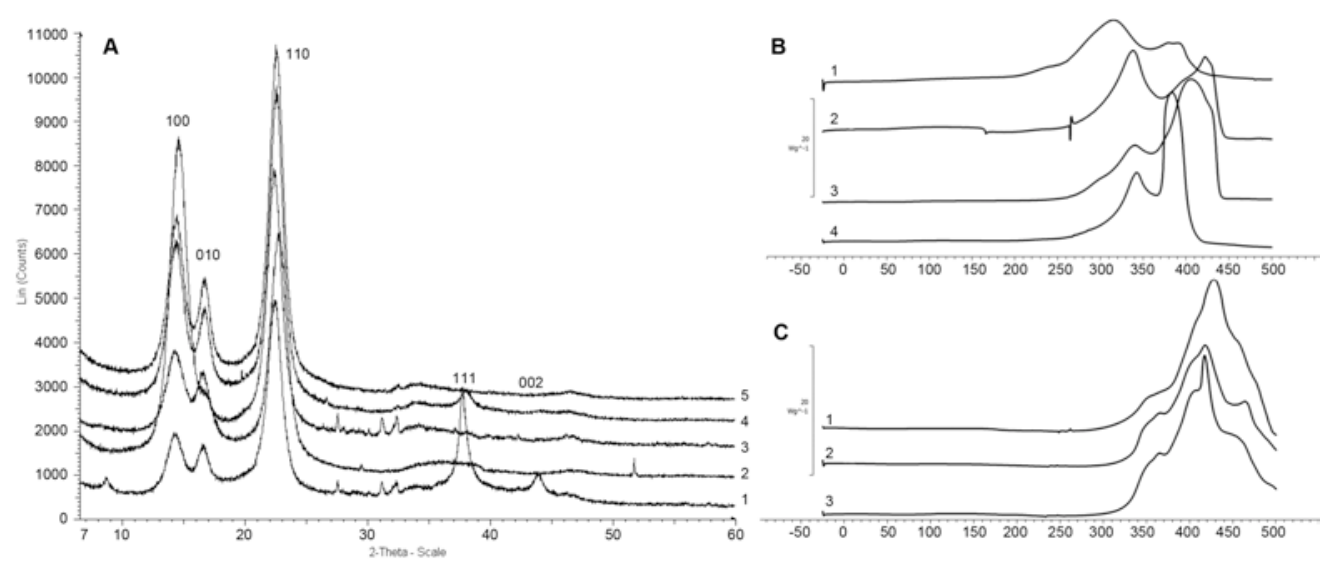

Fig. 4. Physicochemical properties of composites: A - X-ray patterns of the BC/AgNp composite produced at different $\mathrm{AgNO} 3$ concentrations in the reaction solution: $1-0.01 \mathrm{M} ; 4-0.001 \mathrm{M} ; 5-0.0001 \mathrm{M}$, respectively, the degree of crystallinity $\left(\mathrm{C}_{\mathrm{x}}\right) 61,83$, and $86 \% ; 2$ and 3 - pristine cellulose (without silver), the degree of crystallinity 72 and $75 \%$; B - DSC curves: 1 - pristine cellulose, freeze-dehydrated; 2, 3 and 4 - the composite produced at 90 ${ }^{\circ} \mathrm{C}$ and different concentrations of $\mathrm{AgNO} 3(0.01 \mathrm{M}, 0.001 \mathrm{M}$, and $0001 \mathrm{M}$, respectively); $\mathrm{C}-1,2-\mathrm{BC} /$ ceftriaxone $1 \%$ and $4 \%, 3-\mathrm{BC} /$ amikacin $1 \%$ the BC composite with, antibiotics, respectively.

In a study by French (2014) [40], three characteristic peaks were identified in radiograms of freeze-dried $\mathrm{BC}$ films - in the $14.60^{\circ}, 16.82^{\circ}$, and $22.78^{\circ}$ ranges; the peaks corresponded to (110), (110), and (200) crystal planes of cellulose. This is in good agreement with the results of X-ray diffraction analysis obtained in this study and data in Figure 5a, indicating the main reflexes corresponding to cellulose crystal $\mathrm{I} \alpha$ with the calculated parameters $\boldsymbol{a}=6.72, \boldsymbol{b}=5.96, \boldsymbol{c}=10.40 \AA ; \boldsymbol{\alpha}=118.1^{\circ}, \boldsymbol{\beta}=114.8^{\circ}, \boldsymbol{\gamma}=80.4^{\circ}$ and axis $\boldsymbol{c}$ parallel to the molecular axis. Positions of these reflexes differ between samples, e.g., (100) varies between $14.24^{\circ}$ and $14.52^{\circ}$. The presence of nanosilver in the composites is confirmed by the strong reflexes with coordinates $2 \theta=37.72^{\circ}$ and $43.89^{\circ}$ in radiogram 1 (a BC/AgNp sample produced at the highest AgNO3 concentration in the reaction solution). Their positions are consistent with reflexes (111) and (002) of crystalline silver at a cell parameter of $4.126 \AA$. Their large width must be due to the small size of silver nanoparticles.

Analysis of radiograms did not show any significant changes in the $\mathrm{C}_{\mathrm{x}}$ value of $\mathrm{BC}$ composites with nanosilver. The degree of crystallinity of the samples produced at the lowest $\mathrm{AgNO}_{3}$ concentration in the system $(0.0001 \mathrm{M})$, with the low content of silver in the composite $\left(0.044 \mathrm{mg} / \mathrm{cm}^{2}\right)$, and with nanoparticles of an average size of $13 \mathrm{~nm}$, was $61 \%$. With an increase in the content of silver nanoparticles in the composite from 0.16 to 0.37 $\mathrm{mg} / \mathrm{cm}^{2}$, the degree of crystallinity did not increase significantly; it was 73 and $78 \%$, respectively, which was closer to the $\mathrm{C}_{\mathrm{x}}$ of pristine $\mathrm{BC}$. Similar data were reported by other authors. The $\mathrm{C}_{\mathrm{x}}$ of $\mathrm{BC}$ films varied considerably, between 46.7 and $91.62[41-43 ; 25]$. [38] reported the degree of crystallinity of $\mathrm{BC} /$ silver composites of 83.68$86.21 \%$, which was close to the $\mathrm{C}_{\mathrm{x}}$ of pristine $\mathrm{BC}$. Comparable $\mathrm{C}_{\mathrm{x}}$ values were obtained for the composites with nanosilver synthesized in the presence of $\mathrm{NaBH}_{4}$ as a reductant [44-45]. Thus, the crystalline structure and the degree of crystallinity of BC did not change considerably with silver nanoparticles synthesized in situ.

The maximal temperature of decomposition of a material is a criterion of its thermal stability. Thermal decomposition of $\mathrm{BC}$, as shown in a number of studies, is determined by certain structural parameters such as molecular weight, degree of crystallinity, and fiber alignment of the BC [46-47]. Differences in thermal stability between pristine $\mathrm{BC}$ samples are caused by different conditions of their synthesis. As the region of degradation has no pronounced peaks, it seems reasonable to speak of the decomposition onset temperature $\left(\mathrm{T}_{\text {dec. onset }}\right)$. The $\mathrm{BC}$ samples synthesized in the medium with galactose had the highest thermal stability, and $\mathrm{T}_{\text {dec. onset }}$ was $284^{\circ} \mathrm{C}$. The BC samples synthesized in the medium with sucrose had the lowest $\mathrm{T}_{\text {dec. onset }}\left(220^{\circ} \mathrm{C}\right)$. For all samples, we observed two sections in the decomposition region. The first section corresponded to a temperature range of between $220^{\circ} \mathrm{C}$ and $285^{\circ} \mathrm{C}$. In this section, the loss of $\mathrm{BC}$ mass was insignificant. The second section corresponded to a temperature range of between $360^{\circ} \mathrm{C}$ and $430^{\circ} \mathrm{C}$. The loss of $\mathrm{BC}$ mass in this section was more substantial, as the rate of thermal decomposition processes increased. A study by F. Mohammadkazemi et al. [41] also showed that the onset of thermal decomposition of $\mathrm{BC}$ could occur in the range between 200 and $250^{\circ} \mathrm{C}$, but more noticeable decomposition, with the samples losing $70-80 \%$ of their weight, was observed at $360-390^{\circ} \mathrm{C}$. This is consistent with the data reported by other authors [48], showing the weight loss of the $\mathrm{BC}$ sample during thermal decomposition at $300^{\circ} \mathrm{C}$ and higher rates of this process at $350-370^{\circ} \mathrm{C}$.

Unlike BC, BC composites with silver nanoparticles produced under different conditions were not identical to each other and were characterized by greater thermostability (Fig. 4 B). Thus, composites produced at different temperatures but having similar contents of silver had more pronounced peaks in the thermal decomposition region 
(415-425 ${ }^{\circ} \mathrm{C}$ ) than BC. The onset of the decomposition temperature for the samples was in the region of $320-325^{\circ} \mathrm{C}$ (Fig. $4 \mathrm{~B}$ ), and that was significantly, almost $60-80{ }^{\circ} \mathrm{C}$, higher than in the $\mathrm{BC}$ samples produced earlier. The composites produced by stabilizing the temperature but with different concentrations of $\mathrm{AgNO}_{3}$ in the reaction medium also showed higher thermal stability than the BC (Fig. 4 B, curve 1). In all composite samples, the regions of onset of thermal decomposition were shifted to the right relative to the $\mathrm{BC}$; at the same time, they were characterized by the presence of two peaks with a gap between them of between 40 and $120{ }^{\circ} \mathrm{C}$ (Fig. 4 b, curves 2 4). Analysis of $\mathrm{BC}$ composites with antibiotics did not reveal any significant changes in temperature parameters compared to pristine BC (Fig. 4 C). Thus, incorporation of silver nanoparticles into cellulose films increased thermal stability of BC. A similar enhancement of thermal stability of BC composites with nanosilver was reported by other authors [24-25].

An important property of a medical device is the ability to retain its integrity throughout its lifetime. Mechanical properties of BC are largely determined by the BC producer used, conditions of synthesis, fibril thickness, and method of drying of the films. The tensile strength of air-dried BC films varies between 129 and 198 MPa [49], while the tensile strength of freeze-dried ones is an order of magnitude lower (8-14 MPa) [3; 50]. Results of measuring physical/mechanical properties of $\mathrm{BC}$ and $\mathrm{BC}$ composites are listed in Table 2 . The properties of the samples differ substantially depending on the moisture content of the sample. Mechanical parameters of wet pristine BC samples taken out of the fermentation medium and rinsed to remove the medium and bacterial cells, with a moisture content of over 90\%, were as follows: Young's modulus 10.26 $\pm 0.35 \mathrm{MPa}$, tensile strength $0.75 \pm 0.34 \mathrm{MPa}$, and elongation at break $5.49 \pm 1.21 \%$. The dry films, with a low moisture content $(5-7 \%)$ only differed from the wet ones in their Young's modulus, which was 6 times higher. Composite films with residual moisture content of about $50 \%$ exhibited the highest mechanical strength parameters, which were an order of magnitude higher than the corresponding parameters of dry and wet BC samples: 47.60 $\pm 6.32 \mathrm{MPa}, 0.11 \pm 0.13 \mathrm{MPa}$, and $4.35 \pm 0.82 \%$, respectively.

Table 2. - Physical/mechanical properties of BC and BC/AgNp and BC/antibiotic composites

\begin{tabular}{|c|c|c|c|}
\hline Samples & Young's modulus (MPa) & Tensile strength (MPa) & Elongation at break (\%) \\
\hline $\begin{array}{c}\text { Pristine BC (dry), moisture } \\
\text { content 5-7 \% }\end{array}$ & $63.9 \pm 8.52$ & $0.52 \pm 0.09$ & $3.35 \pm 0.61$ \\
\hline $\begin{array}{c}\text { Pristine BC (wet), moisture } \\
\text { content 95-97\% }\end{array}$ & $10.26 \pm 0.35$ & $0.75 \pm 0.34$ & $5.49 \pm 1.21$ \\
\hline $\begin{array}{c}\text { BC (dry, moisture content } \\
\text { 50-55\% }\end{array}$ & $47.60 \pm 6.32$ & $0.11 \pm 0.13$ & $4.35 \pm 0.82 \%$ \\
\hline \multicolumn{2}{|c|}{ BC/AgNps (dry, moisture content 50-55\%) } \\
\hline BC/AgNps 0.0001 M & $233 \pm 5.21$ & $14.96 \pm 1.69$ & $9.8 \pm 2.57$ \\
\hline BC/AgNps 0.001 M & $218 \pm 2.21$ & $13.22 \pm 2.05$ & $11.73 \pm 1.631$ \\
\hline BC/AgNps 0.01 M & $99.3 \pm 5.21$ & $9.93 \pm 1.27$ & $9.02 \pm 2.1$ \\
\hline \multicolumn{2}{|c|}{ BC/antibiotics (dry, moisture content 50-55\%) } \\
\hline BC+amikacin 0.2\% & $110.19 \pm 13.5$ & $7.18 \pm 1.5$ & $14.36 \pm 2.5$ \\
\hline BC+amikacin 0.6\% & $90.16 \pm 14.4$ & $9.27 \pm 1.4$ & $11.69 \pm 2.1$ \\
\hline BC+amikacin 1\% & $63.24 \pm 1.8$ & $6.07 \pm 1.8$ & $11.9 \pm 2.7$ \\
\hline BC+ceftriaxone 1\% & $58.94 \pm 6.9$ & $6.3 \pm 0.9$ & $17.62 \pm 1.1$ \\
\hline BC+ceftriaxone 4\% & $44.57 \pm 4.2$ & $6.03 \pm 1.1$ & $16.25 \pm 2.5$ \\
\hline BC+ceftriaxone 6\% & $45.47 \pm 8.1$ & & \\
\hline
\end{tabular}

Loading of nanosilver into BC considerably changed mechanical properties of BC, increasing the values of Young's modulus and elongation at break by one order of magnitude and tensile strength by two orders of magnitude compared to pristine BC (Table 2). It is difficult to compare results obtained in this study with the published data, as the literature data vary considerably, which may be attributed to different methods employed to produce BC composites and dissimilar properties of pristine BC. In a study by Y.Wan et al. [51], tensile strength of freeze-dried BC samples with longitudinal fibers was 1.2 MPa, and that was somewhat higher than tensile strength of pristine $\mathrm{BC}(0.9 \mathrm{MPa})$ and $\mathrm{BC}$ with transverse orientation of the fibers $(0.6 \mathrm{MPa})$. However, elongation at break of the $\mathrm{BC}$ with parallel fibers was $22 \%$, i.e. lower than the elongation at break of pristine $\mathrm{BC}(30 \%)$ and $\mathrm{BC}$ with fibers oriented perpendicular to each other (39\%). These data suggest that physical/mechanical parameters are determined by the orientation of fibers in BC films. In a study by V. Sadanand et al. [17], parameters of mechanical strength of $\mathrm{BC}$ are considerably higher than the values reported by Y.Wan et al. [51] but comparable to those obtained in the present study: tensile strength of the composite BC/AgNp films was $80 \mathrm{MPa}$, which was higher than that of pristine $\mathrm{BC}(50 \mathrm{MPa})$, while elongation at break dropped from 11 to $5 \%$ as $\mathrm{AgNO} 3$ concentration was increased. In another study V. Sadanand et al. [52], however, strength parameters of the composite BC/CuNP films were different: their tensile strength was $100 \mathrm{MPa}$, which was lower than tensile strength of pristine BC (125 MPa), and it decreased with an increase in concentration of copper sulfate solution used to prepare CuNPs, but elongation at break was higher in the composites $(25 \%)$ than in $\mathrm{BC}(20 \%)$. This could be explained by the properties of the 
filler (CuNPs) and a decrease in the size of composite crystals, but the authors did not report moisture content of the samples. The authors of one more study [19] investigated mechanical properties of BCAgNP composite prepared by immersion of $\mathrm{BC}$ in 1-5 $\mathrm{mM} \mathrm{AgNO}_{3}$ solutions for $24 \mathrm{~h}$, under continuous stirring. The tensile strength of the composite was $108 \mathrm{MPa}$, and it was considerably higher than the tensile strength of pristine BC (59 MPa). This parameter decreased with an increase in AgNP content of the composite, to $70 \mathrm{MPa}$, which the authors attributed to agglomeration of AgNPs with an increase in AgNP content. These data are in good agreement with the results obtained in the present study. Thus, in most of the studies, loading of nanosilver into BC led to enhancement of mechanical strength of the films. Mechanical properties of BC composites with antibiotics were generally lower than those of BC/AgNp composites. Young's modulus of BC composites with amikacin tended to decrease (from 110.19 to $63.24 \mathrm{MPa}$ ) with an increase in the content of the antibiotic in the composite while tensile strength and elongation at break ranged between 6.07 and $9.27 \mathrm{MPa}$ and between 11.69 and $14.36 \%$, respectively, and these values were comparable to the strength parameters of $\mathrm{BC}$ composites with nanosilver. Tensile strength and elongation at break of $\mathrm{BC} /$ ceftriaxone composites were similar to the corresponding parameters of $\mathrm{BC} / \mathrm{amikacin}$. At the same time, Young's modulus of BC/ceftriaxone was considerably lower than that of BC/AgNps (8-10 times lower) and BC/amikacin (1.5-2.0 times lower). Thus, mechanical properties of BC composites with antibiotics were comparable with mechanical properties of pristine $\mathrm{BC}$, and mechanical properties of $\mathrm{BC} / \mathrm{AgNp}$ composites were superior to them. That is, incorporation of nanosilver into BC reinforced mechanical strength of BC.

One of the factors determining biocompatibility of implants is physicochemical reactivity of their surface. The main factors that influence surface interaction with blood and tissue cells and components of biological fluids are surface topography, microstructure, and adhesive properties. An indirect indicator of surface hydrophilicity is liquid contact angle. Properties of BC composites are listed in Table 3. BC films are inherently quite hydrophilic, with the water contact angle below $50^{\circ}\left(45.5 \pm 17.6^{\circ}\right)$. The surfaces of BC/AgNp composites tend to become less hydrophilic (more hydrophobic) as their silver content increases. The dispersive and polar components increase, too. Such changes reduce fouling of the surfaces by proteins and cells, as described in a study by Baoquan Jia et al.[53]. The authors of that study observed an increase in water contact angle on BC/CuNp composite films to $110 \pm 0.4^{\circ}-$ the value that was twice higher than that of the water contact angle on the pristine $\mathrm{BC}\left(50.1 \pm 1.8^{\circ}\right)$.

\subsection{Production and properties of BC composites with antibiotics}

In order to impart bactericidal properties to cellulose, we prepared $\mathrm{BC}$ composites with antibacterial drugs (amikacin and ceftriaxone). Amikacin and ceftriaxone were chosen for the following reasons. Ceftriaxone is a thirdgeneration durable antibiotic, which is active in vitro against most of the Gram-negative and Gram-positive microbes. The antibacterial activity of cephalosporins and other $\beta$-lactam antibiotics is determined by inhibition of synthesis of peptidoglycane - the structural basis of microbial wall. The mechanism of action of the aminoglucoside antibiotic amikacin is based on its irreversible binding to specific receptors of bacterial ribosomes and inhibition of synthesis of cytoplasmic membranes, which causes the death of bacterial cells. Amikacin is active against aerobic Gram-negative microorganisms, especially Serratia spp., Enterococcus faecalis, and Staphylococcus aureus, but it is less effective against most of Gram-positive bacteria.

During preparation of the composites, concentrations of antibiotics in the solutions varied between $0.1-0.2$ and 1-6\%. SEM images show that BC films impregnated with antibiotics had a denser and more uniform surface (Fig. 5).

In contrast to silver nanoparticles, antibiotics impregnated into BC did not significantly change the degree of crystallinity and temperature properties of composite films, but affected their surface properties (Table 3). BC composites with antibiotics, like BC/AgNps, had more hydrophobic surfaces than pristine BC films; their dispersive components and surface energies were higher too. SEM images showed changes in the film structure after addition of antibiotics: the distances between BC fibers decreased and they formed a uniform layer.
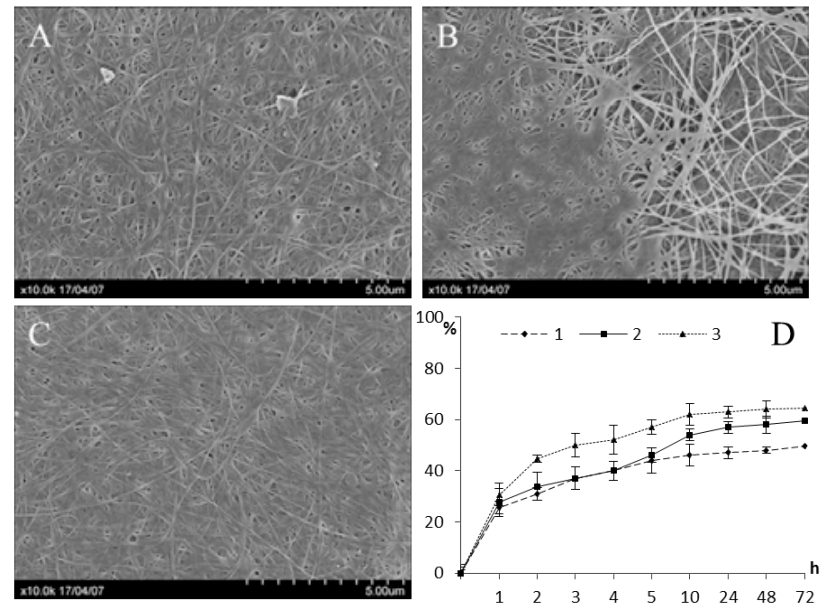
Fig. 5. SEM images of BC/antibiotic composite films: A - BC/amikacin 1\%; B - BC/ceftriaxone 1; C $\mathrm{BC} /$ ceftriaxone $6 \%$; $\mathrm{D}$-in vitro release of antibiotics to the balanced phosphate-buffered saline: $1-$ amikacin $1 \%$; 2 - ceftriaxone $1 \% ; 3$ - ceftriaxone $6 \%$.

Table 3 - Surface properties of BC/AgNp and BC/antibiotic composites

\begin{tabular}{|c|c|c|c|}
\hline Samples & $\begin{array}{c}\text { Water contact angle, } \\
\text { degrees }\left[{ }^{\circ}\right]\end{array}$ & $\begin{array}{c}\text { Dispersive component } \\
{[\mathrm{mN} / \mathrm{m}]}\end{array}$ & $\begin{array}{c}\text { Polar component } \\
{[\mathrm{mN} / \mathrm{m}]}\end{array}$ \\
\hline Pristine BC & $45.5 \pm 17.6$ & $28 \pm 9.24$ & $17.5 \pm 8.37$ \\
\hline \multicolumn{3}{|c|}{ BC/AgNps } \\
\hline BC/AgNps 0.0001M & $50.3 \pm 4.61$ & $42.6 \pm 1.01$ & $27.7 \pm 3.6$ \\
\hline BC/AgNps 0.001M & $68.8 \pm 1.76$ & $46.2 \pm 0.99$ & $22.6 \pm 0.77$ \\
\hline BC/AgNps0.01M & $69 \pm 2.71$ & $44.9 \pm 1.85$ & $25.1 \pm 0.86$ \\
\hline BC+amikacin 0.2\% & $67.1 \pm 2.12$ & $42.2 \pm 4.15$ & $25.1 \pm 2.04$ \\
\hline BC+amikacin 0.6\% & $66.5 \pm 2.56$ & $40.3 \pm 12.69$ & $25.8 \pm 8.87$ \\
\hline BC+amikacin 1\% & $70.4 \pm 2.11$ & $44.3 \pm 1.07$ & $24.7 \pm 1$ \\
\hline BC+ceftriaxone 1\% & $70.2 \pm 2.40$ & $42.5 \pm 2.11$ & $25.7 \pm 1$ \\
\hline BC+ceftriaxone 4\% & $68.4 \pm 1.10$ & $47.3 \pm 13.1$ & $24.2 \pm 2.21$ \\
\hline BC+ceftriaxone 6\% & $72.4 \pm 1.26$ & & $23.2 \pm 1.13$ \\
\hline
\end{tabular}

Release of antibacterial drugs from BC composites was investigated in the phosphate-buffered saline (PBS) at $37^{\circ} \mathrm{C}$ and $\mathrm{pH}=7$ for $72 \mathrm{~h}$ (Fig. $5 \mathrm{D}$ ). No burst release of antibiotics from the BC matrix was observed, suggesting adhesion between $\mathrm{BC}$ and antibiotics. Antibiotics were being released from the composites during the whole $72 \mathrm{~h}$ experiment, but release kinetics depended on the antibiotic type and the level of loading of the BC matrix with it. The highest percentage of the drugs were released over the first ten hours. By the end of the $72 \mathrm{~h}$ experiment, $49.5 \%$ of amikacin was released from the BC/amikacin $1 \%$. Ceftriaxone was released at a higher rate, probably because of its weaker adhesion to $\mathrm{BC}$ : its charge is -1 , in contrast to the positively charged amikacin. The $1 \%$-ceftriaxone composite released $59.5 \%$ of the antibiotic and the $6 \%$-ceftriaxone composite $64.5 \%$ over the $72 \mathrm{~h}$ experiment. Thus, BC composites with antibiotics are rather stable in the liquid medium, which may be important if they are used as wound dressings for treating contaminated wounds and tissues. Our results are consistent with the published data that showed the feasibility of loading tetracycline into BC and slow release of the antibiotic from the dialysis sac $(80 \%$ for $3 \mathrm{~h})$ compared to the release of the free drug. The authors explained this result by the different charges of the drug and $\mathrm{BC}$. BC is charged negatively while the antibiotic has a positive charge, and the electrostatic interaction between BC and the drug slowed down tetracycline release [29]. Slow release of tetracycline from nanocrystals was described in another study [30]. The authors revealed the effect of $\mathrm{pH}$ of the medium on this process: the highest release of tetracycline $(82.21 \%)$ was observed at $\mathrm{pH} 7.2$ and the lowest $(25.1 \%)$ at $\mathrm{pH} 2.1 \mathrm{In}$ yet another study [28], 66\% of benzalkonium chloride incorporated in freeze-dried BC films was released from the matrix over $24 \mathrm{~h}$. The authors suggested that the rate of drug release was determined by the water content of the swollen hydrogel and the parameters of the network such as the degree of crosslinking and the size of fibers. In addition to that, drug release depended on the diffusion coefficient of small molecules or macromolecules through the gel network.

\subsection{Protein adsorption on the surface of BC/AgNp and BC/antibiotic composites}

Nonspecific protein adsorption on the surface is an important process for implants, which come in contact with human body fluids, as it may cause thrombus formation, bacterial adhesion, and immune responses [54]. The generally accepted hypothesis of antiadhesive activity of hydrated coatings is based on the ability of the hydrophilic component to strongly bind water and, thus, create a hydrating layer, which prevents adhesion of nonspecific proteins and bacteria [55]. As mentioned above, the magnitude of the water contact angle of BC composites with silver and antibiotics ranged between 50 and $70^{\circ}$ depending on the concentrations of the components. This is the intermediate position between hydrophobic and hydrophilic surfaces.

Adhesive properties of the surface of BC composites were evaluated in bovine serum albumin (BSA) protein assay. We measured the optical density of protein solutions in which composite samples had been incubated and ones used to incubate pristine BC films. Initial optical density of the protein solution was 0.3 , which corresponded to protein concentration of $860 \mathrm{mg} / \mathrm{ml}$ (Fig. 6). 

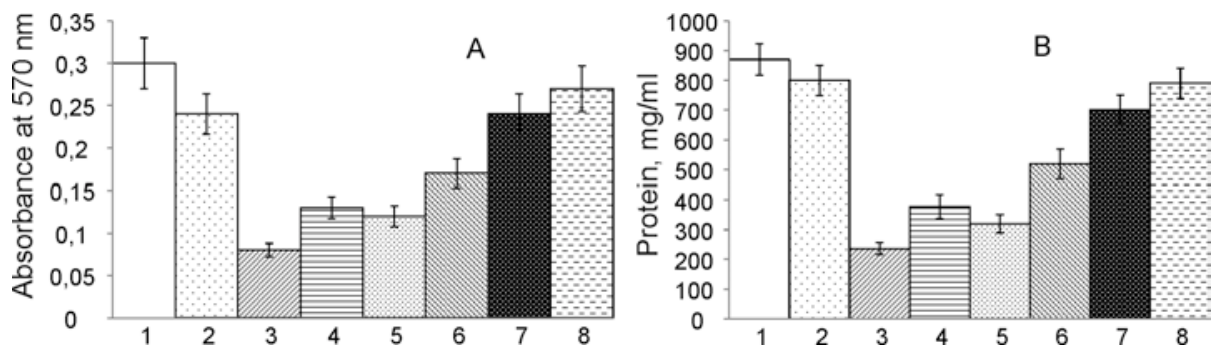

Fig. 6. BSA adsorption (A - relative value (optical density of protein solution) ,B - quantitative data (protein concentration, $\mathrm{mg} / \mathrm{ml}$ ): 1 - control (initial protein content); 2 - initial cellulose; 3 - BC/AgNps $0.01 \mathrm{M} ; 4$ BC/AgNps $0.001 \mathrm{M} ; 5$ - BC/AgNps $0.0001 \mathrm{M} ; 6$ - BC/amikacin 1\%; 7 - BC/ceftriaxone 4\%; 8 - BC/ceftriaxone $6 \%$ after $24 \mathrm{~h}$.

Pristine cellulose, whose surface was more hydrophilic than the surface of BC composites, had the most pronounced antiadhesive properties towards protein and did not adsorb it. Protein, taking into account the isoelectric point 4.7 , under physiological conditions, has negative charge of the molecule; therefore, pristine cellulose, which was also negatively charged, did not adsorb it. Adsorption of protein on the pristine BC films was low: protein concentration in the solution had changed very little, measuring $800 \mathrm{mg} / \mathrm{ml}$. This is consistent with the hypothesis suggesting that hydrophilic surfaces have the ability to strongly bind water and, thus, create a hydration layer that prevents adhesion of proteins and bacteria [56].

The amounts of protein adsorbed on composite samples were higher and differed considerably depending on the type of the bactericidal component (silver or antibiotics) and its concentration. The largest amounts of protein were adsorbed on the BC/AgNp composites: $250-320 \mathrm{mg} / \mathrm{ml}$, with no substantial silver concentration dependence. Hence, more than half of the protein from the solution was adsorbed on the surface of BC/AgNp composites. This may be caused by protein-nanoparticles hydrophobic interactions, which can be attributed to albumin having eleven hydrophobic binding domains. These interactions were previously described for gold nanoparticles [57].

A different result was obtained for the BC/antibiotic composites. Their adhesive properties towards BSA were considerably lower although the films of BC/AgNp and BC/antibiotic composites had similar water contact angles (Fig. 6). The composites produced in this study had less hydrophilic (i.e. more hydrophobic) surface than BC and adsorbed protein, but the degree of adsorption varied. Amikacin, being a positively charged compound, adsorbed insignificant amounts of protein. By contrast, ceftriaxone has a charge of -1 at neutral $\mathrm{pH}$, and $\mathrm{BC}$ is also negatively charged. Thus, the negatively charged bovine serum albumin weakly adhered to the composite. As the concentration of the negatively charged ceftriaxone in the composite was increased, the antiadhesive properties of the composite decreased, which was consistent with the decrease in protein sorption observed in our study. The lowest protein adsorption was observed in the experiments with the BC impregnated with 4 and $6 \%$ ceftriaxone, in which protein concentrations in the post-incubation solutions were 700 and $800 \mathrm{mg} / \mathrm{ml}$, respectively. These values were comparable to those obtained in the assay of the pristine $\mathrm{BC}$, which, together with rather low ceftriaxone retention efficiency, suggested a modest effect of this antibiotic on the adhesive properties of BC. The antiadhesive property of the surface is a favorable factor, as implants with antiadhesive properties will be less prone to be "coated" with adsorbed proteins and other components of blood and tissue fluids, preventing microbial colonization and formation of biofilms on their surfaces. A search of the literature did not reveal any studies on protein adsorption on films of BC composites with silver and antibiotics. X. Xu et al. [58] reported that as the surface hydrophilicity of the mucin/poly(ethyleneimine) films was increased, protein adsorption decreased due to the ability of the hydrophilic component, which strongly bound water and, thus, created a hydration layer, to prevent adhesion of nonspecific proteins and bacteria.

\subsection{Antibacterial activity of BC/AgNp and BC/antibiotic composites}

All samples of BC composites exhibited bactericidal activity against test microbial cultures - the most common representatives of nosocomial infection and pathogenic microflora of contaminated wounds. However, the levels of antibacterial activity of the composites were different (Table 4, Fig. 7). BC/antibiotic composites had stronger inhibitory effect on the growth of pathogenic microorganisms.

Table 4 - Inhibition of pathogenic bacteria on solid medium by BC/AgNp and BC/antibiotic composites

\begin{tabular}{|c|c|c|c|c|}
\hline \multirow{2}{*}{ Samples } & \multicolumn{4}{|c|}{ Diameter of inhibition zones (mm) } \\
\cline { 2 - 5 } & P. aeruginosa & E.coli & St.aureus & K. pneumoniae \\
\hline Pristine BC & - & - & - & - \\
\hline \multicolumn{5}{|c|}{ BC/AgNps, M } \\
\hline $0.001 \mathrm{M}$ & $12 \pm 0.44$ & $11 \pm 0.20$ & $15 \pm 0.73$ & $13 \pm 0.44$ \\
\hline $0.01 \mathrm{M}$ & $13 \pm 1.15$ & $13 \pm 0.50$ & $14 \pm 0.28$ & $14 \pm 0.64$ \\
\hline
\end{tabular}




\begin{tabular}{|c|c|c|c|c|}
\hline $0.01 \mathrm{M}$ & $14 \pm 2.11$ & $14 \pm 0.61$ & $15 \pm 1.58$ & $15 \pm 0.36$ \\
\hline \multicolumn{5}{|c|}{ BC+amikacin, \% } \\
\hline $0.2 \%$ & $24 \pm 0.34$ & $15 \pm 0.58$ & $19 \pm 0.6$ & $23 \pm 0.12$ \\
\hline $0.6 \%$ & $30 \pm 0.26$ & $20 \pm 0.9$ & $22 \pm 0.222$ & $24 \pm 0.32$ \\
\hline $1.0 \%$ & $34 \pm 0.49$ & $21 \pm 0.44$ & $26 \pm 0.8$ & $25 \pm 0.30$ \\
\hline \multicolumn{5}{|c|}{ BC+ceftriaxone, \% } \\
\hline $0.2 \%$ & $19 \pm 0.64$ & - & - & - \\
\hline $0.6 \%$ & $19 \pm 0.44$ & - & $16 \pm 0.77$ & $17 \pm 0.50$ \\
\hline $1.0 \%$ & $24 \pm 0.33$ & - & $18 \pm 0.4$ & $19 \pm 0.36$ \\
\hline $4.0 \%$ & $24 \pm 0.31$ & $25 \pm 0.43$ & $32 \pm 0.32$ & $23 \pm 0.8$ \\
\hline $6.0 \%$ & $33 \pm 0.40$ & $29 \pm 0.35$ & $34 \pm 0.50$ & $24 \pm 0.34$ \\
\hline "-" - no zone of inhibition
\end{tabular}
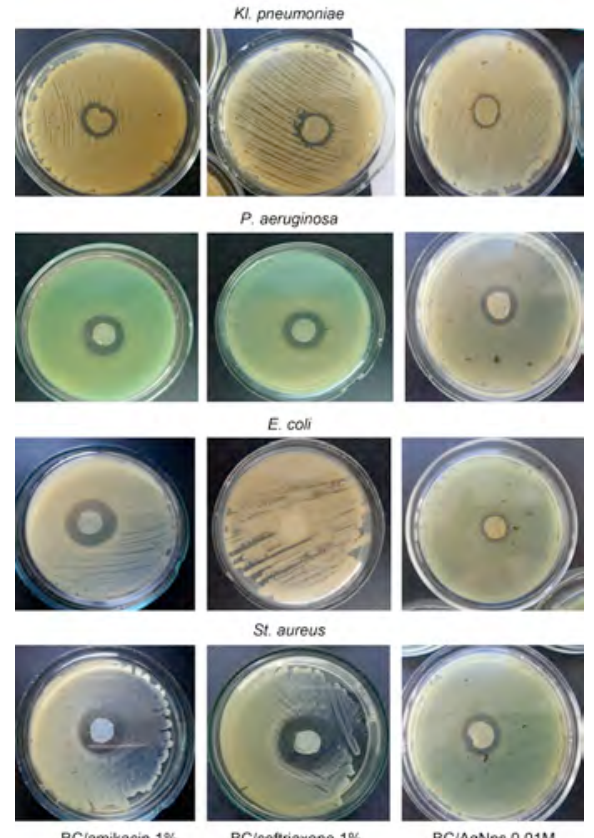

Fig 7. Zones of inhibition of Klebsiella pneumoniae, Pseudomonas aeruginosa, Escherichia coli, and Staphylococcus aureus by the $\mathrm{BC} / \mathrm{AgNp} 0.01 \mathrm{M}$ and $\mathrm{BC} /$ amikacin $1 \%$ and $\mathrm{BC} /$ ceftriaxone $1 \%$ composites.

In experiments with BC/AgNps, the largest zone of inhibition $(15 \pm 1.58 \mathrm{~mm})$ was observed for St. aureus, at the highest concentration of silver nanoparticles $(\mathrm{AgNps} 0.01 \mathrm{M})$; the smallest zone of inhibition $(11 \pm 0.20 \mathrm{~mm}) \mathrm{was}$ created by BC/AgNps $0.0001 \mathrm{M}$ for E. coli. These differences are caused by different susceptibility of bacteria to $\mathrm{BC}$ composites with Ag particles, their cell structure and physiology. Gram-positive bacteria are generally more susceptible to the bactericidal effect of Ag nanoparticles [59]. Similar data were reported by W. Shao et al. [29]: in their study, at a concentration of BC-Ag of $0.01 \mathrm{M}$, the diameters of the zones of inhibition of E.coli and St. aureus growth were $11.7 \pm 0.1$ and $11.6 \pm 0.1 \mathrm{~mm}$, respectively J. Feng et al., [11] reported a study of BC composites with silver reduced using $\mathrm{NaBH} 4$, which created zones of inhibition of diameter about $16.1 \mathrm{~mm}$ for E. coli and $17.7 \mathrm{~mm}$ for $S$. aureus; the BC composites with silver reduced with sodium citrate created zones of inhibition with smaller diameters: 13.7 and $13.2 \mathrm{~mm}$, respectively. The diameters of the zones of inhibition of B.subtilis and E. coli by composites based on polydopamine magnetic bacterial cellulose and Ag were $20 \mathrm{~mm}$ and $17 \mathrm{~mm}$, respectively [10]. However, a study by S.H. Barud et al. [60] showed that composite membranes of BC/Ag/TEA 1 mol/ $/ \mathrm{L}^{-1} \mathrm{created}$ inhibition zones for P.aeruginosa ATCC-27853, E.coli ATCC 25922, and St.aureus ATCC 25923 reaching 20 mm. Differences between results may be caused by different methods employed to produce composites, sizes of silver nanoparticles, and their concentrations in BC films. It has been assumed that the lowest inhibitory concentration of $\mathrm{Ag}$ nanoparticles is about $0.05-0.1 \mathrm{mg} / \mathrm{ml} \mathrm{[10].} \mathrm{In} \mathrm{the} \mathrm{present} \mathrm{study,} \mathrm{the} \mathrm{strongest} \mathrm{inhibition} \mathrm{of} \mathrm{pathogenic}$ microflora by $\mathrm{BC} / \mathrm{AgNp}$ composites was observed under the highest silver concentration in the reaction solution during composite production, when silver content was 9.1 (or $0.37 \mathrm{mg} / \mathrm{ml}$ ), i.e. these results are consistent with the data reported by other authors. The zone of inhibition of Klebsiella pneumoniae was $14 \pm 0.36 \mathrm{~mm}$ at the highest concentration of silver nanoparticles (AgNps 0.01 M).

Zones of inhibition by BC/antibiotic composites were generally larger than those produced by $\mathrm{BC} / \mathrm{AgNp}$ composites (Table 4). It is well-known that antibiotics penetrate through cell membrane and irreversibly bind to specific receptor proteins of bacterial cell, thus effectively suppressing synthesis of bacterial membranes. 
The strongest inhibition (reaching 30-34 mm) by the BC composite with amikacin (at concentrations of 0.6 and $1.0 \%)$ was observed in the culture of P. aeruginosa; somewhat smaller inhibition zones (20-22 mm) were formed in the two other cultures. Experiments with BC composites with ceftriaxone, especially those with low ceftriaxone concentrations, did not suggest any definite conclusions. The BC films with low ceftriaxone concentrations $(0.6$ and $1.0 \%)$ did not inhibit the growth of the Gram-negative E. coli, Kl. pneumoniae and the Gram-positive S.aureus. The reason why antibacterial activity of ceftriaxone was different against the Gramnegative E.coli and the Gram-positive S.aureus may be the difference between the structures of the outer cell membranes of these microorganisms. Cephalosporins penetrate through the outer cytoplasmic membrane of Grampositive bacteria quite easily and suppress them. The membrane of Gram-negative bacteria has a more complex structure, preventing cephalosporins from penetrating into the periplasmic space of the cell. Cephalosporins penetrate the microbial cell through the so-called porin channels. A possible reason why low concentrations of ceftriaxone did not inhibit $E$. coli might be the difficulty of penetrating into the cell. At higher concentrations, this difficulty was alleviated, and the inhibitory effect became noticeable. At ceftriaxone content of the composite increased to 4 and $6 \%$, its effect was similar to that of amikacin. Thus, the inhibitory effect of the composites varied depending on the type of microorganisms and concentration of the inhibiting agent. B. Wei et al. [28] reported a similar result. The authors used BC films containing benzalkonium chloride at different concentrations (between 0.026 and $0.128 \% \mathrm{w} / \mathrm{w})$. At the highest concentration of the antibiotic, the zones of inhibition of E. coli, St.aureus, and Bacilluss ubtilis were $15,18.5$, and $24.5 \mathrm{~mm}$, respectively.

Antibacterial properties of all experimental BC composites were confirmed using the shake-flask culture method. The inhibitory effects of composites added to the culture medium were studied in two 24-h cultures (E. coli and St.aureus). An indicator of antibacterial activity of the composites was optical density of bacterial suspensions, which corresponded to cell concentration (Fig. 8). BC/AgNp composites produced an inhibitory effect even at the lowest concentration of silver nanoparticles in the composite $(0.0001 \mathrm{M})$, and the strongest inhibition was observed in St. aureus culture. At the highest silver concentration in the composite, the optical density of either culture was no more than 0.17-0.20 (or 0.61-1 $\times 10^{3} \mathrm{CFU} / \mathrm{ml}$ ). That was 3.7-4.0 times lower than in the control and in the test with the pristine BC. Silver activity in liquid culture has been described in a number of papers. In a study by G. Yang et al. [12], BC/AgNp composites prepared using the same method as in this study - by immersion in St. aureus liquid culture for a long time period $(72 \mathrm{~h}$ ) - caused optical density values close to zero (0.08), while in the control (with pristine BC), optical density was higher -1.8 . J. Wu et al. [14], after incubation of BC/AgNp $0.01 \mathrm{M}$ composites for $24 \mathrm{~h}$, noted a $98.8-100 \%$ decrease in E. coli, S. aureus, and P. aeruginosa cells $\left(8.2 \times 10^{2}, 0,1.1 \times 10^{3}\right.$, respectively). The authors of another study [43] proved that the increase in silver concentration $(0.01-0.03 \mathrm{M})$ in BC/AgNp composites produced using NaBH4 caused inhibition of E. coli and S.aureus growth by a factor of 4-4.5 $\left(2 \times 10^{6}\right.$ and $\left.1 \times 10^{6}\right)$ relative to their initial growth. An increase in $\mathrm{AgNO}_{3}$ concentration to 0.04-0.05 M completely suppressed the growth of all cultures.
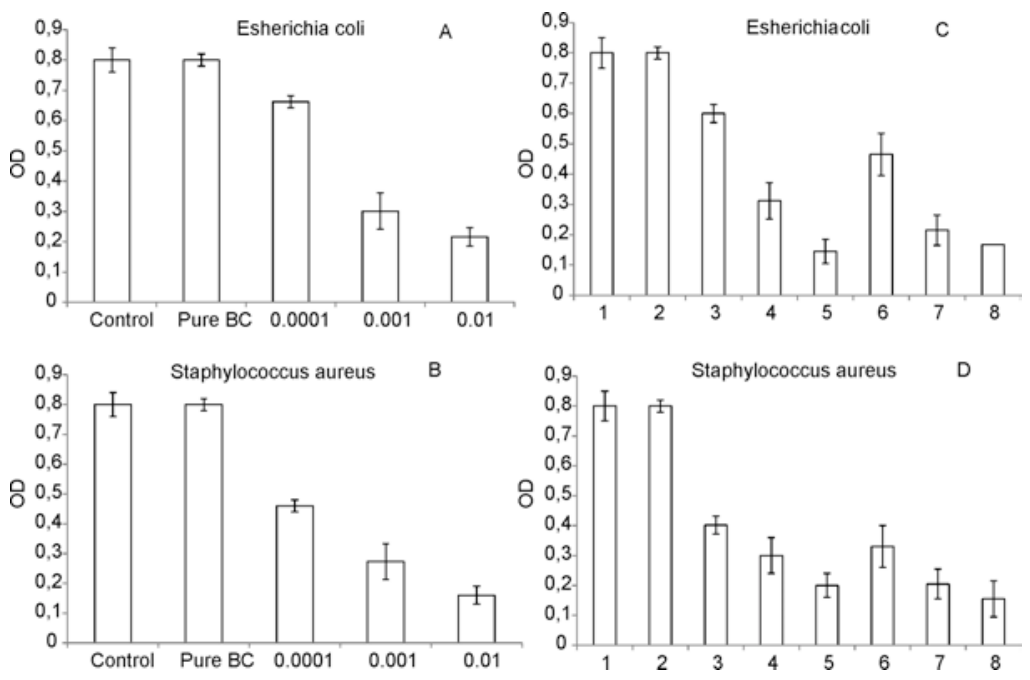

Fig. 8. Optical densities of 24-h cultures of E.coli and St.aureus exposed to effects of BC/AgNp (a, b) and BC/antibiotic (c, d) composites: 1 - control (suspension); 2 - pristine cellulose (without silver); 3 - BC/amikacin $0.2 \% ; 4$ - BC/amikacin 0.6\%; 5 - BC/amikacin 1\%; 6 - BC/ceftriaxone 1\%; 7- BC/ceftriaxone 4\%; 8 BC/ceftriaxone $6 \%$.

Definite antibacterial activity of BC/antibiotic composites was observed in liquid cultures (Fig. 8), and it was also the highest in S.aureus culture. The optical density was 4 times lower in both cultures with the BC/amikacin $1 \%$ composite and with the composites containing higher (4 and 5\%) concentrations of ceftriaxone compared to the control. A similar effect was described by B. Wei et al., [28] in a study in which optical density of St. aureus and B. subtilis cultures containing BC/benzalkonium chloride composites decreased as concentration of the inhibitory agent 
was increased, dropping to 0.077 and 0.003 , respectively, after $24 \mathrm{~h}$. That was 17 times lower than the optical density of the control medium (3.363 and 1.572). In a study by W. Shao et al. [29], BC films with tetracycline hydrochloride $(0.05-0.5 \mathrm{~g} / \mathrm{L})$ were incubated at $37^{\circ} \mathrm{C}$ in E. coli, St. aureus, B. subtilis, and C.albicans suspensions for 6 min. Colony counts showed that BC/antibiotic films inhibited growth of all microorganisms by 99-100\% (E. coli by $99.98 \%, S$. aureus by $100 \%$, B. subtilis by $100 \%$, and C. albicans by $99.99 \%)$, in contrast to pristine BC ( 2.6 $\times 10^{8}$ ).

\subsection{Cytotoxicity assays of BC/AgNp and BC/antibiotic composites in fibroblast cell culture}

As the experimental BC composites were investigated as possible candidates for wound dressings for treating skin defects and injuries, including those contaminated by pathogenic microflora, it was important to study the effect of silver and/or antibiotics impregnated into BC films on dermal cells. BC composites were investigated for their potential cytotoxicity in fibroblast cell culture using DAPI stain - a marker of nuclear DNA - and MTT assay, which determines the number of viable cells.

The evaluation of the effect of BC composites on fibroblasts using DAPI staining was in good agreement with results of MTT assay (Fig. 9-10). At Day 3, only one sample, which contained $0.2 \%$ amikacin, did not show any inhibitory effect. In all other tests, with higher amikacin concentrations and all ceftriaxone concentrations, the number of cells decreased. The most substantial decrease (by 35-40\% relative to the control) was noted in the tests with composites containing ceftriaxone, irrespective of concentration.

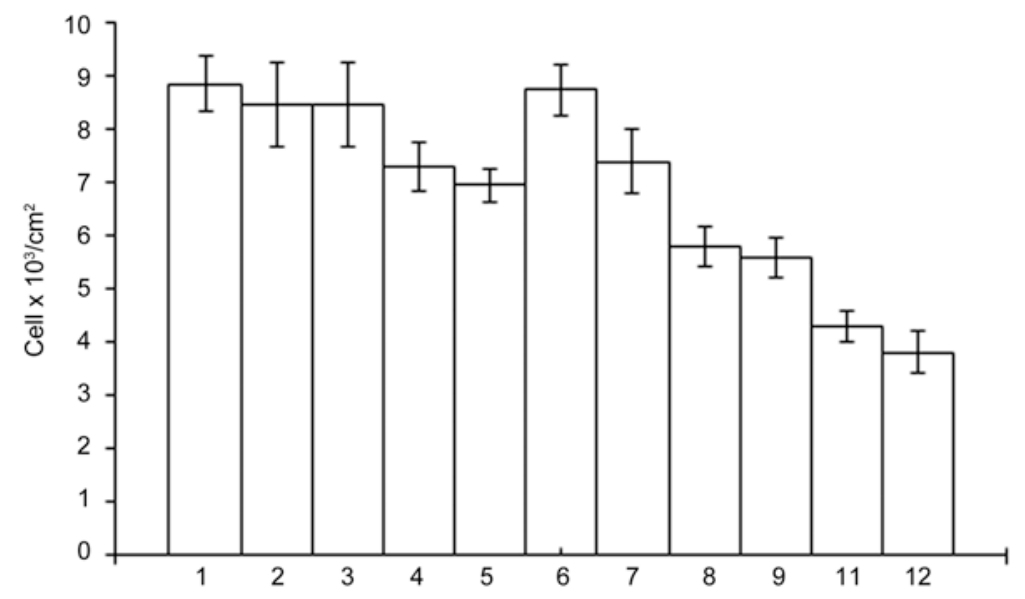

Fig. 9. The number of viable cells (MTT assay) NIH 3T3 mouse fibroblast cells:on composites at Day 3 of the culture: 1 - control; 2 - pristine cellulose (without silver); 3 -BC/AgNps $0.0001 \mathrm{M} ; 4$ - BC/AgNps $0.001 \mathrm{M} ; 5$ BC/AgNps $0.01 \mathrm{M} ; 6$ - BC/amikacin 0.2\%; 7 - BC/amikacin 0.6\%; 8 - BC/amikacin 1\%; 9 - BC/ceftriaxone 1\%; $10-\mathrm{BC} /$ ceftriaxone $4 \% ; 11-\mathrm{BC} /$ ceftriaxone $6 \%$.

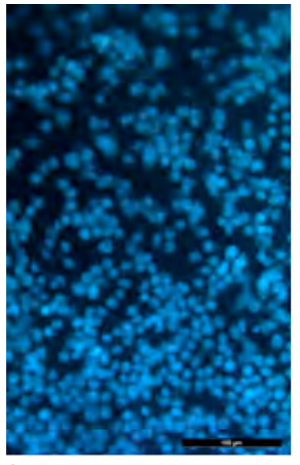

Control

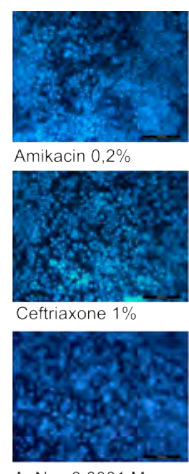

AgNps $0,0001 \mathrm{M}$

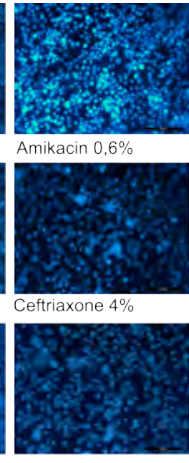

AgNps 0,001 M

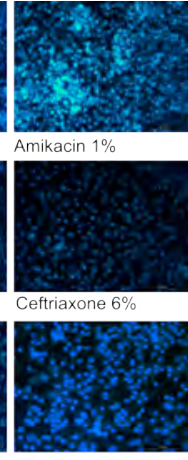

AgNps $0,01 \mathrm{M}$

Fig. 10. The number of viable cells (MTT assay) of NIH 3T3 mouse on BC/antibiotic and BC/AgNps after 3 days: $\mathrm{C}$ - control; 1 - BC/amikacin $0.2 \% ; 2$ - BC/amikacin $0.6 \% ; 3$ - BC/amikacin 1\%; 4 - BC/ceftriaxone $1 \% ; 5-$ $\mathrm{BC} /$ ceftriaxone $4 \% ; 6$ - BC/ceftriaxone $6 \% ; 7$-BC/AgNps $0.0001 \mathrm{M} ; 8$ - BC/AgNps $0.001 \mathrm{M} ; 9$-BC/AgNps 0.01 M.

A similar study in the fibroblast cell culture was performed with BC/AgNp composites (Fig. 9). In contrast to BC/antibiotic composites, neither test (DAPI staining or MTT assay) revealed any significant inhibitory effect of 
silver nanoparticles on fibroblast cell culture. While inhibiting the growth of pathogenic microflora, the BC composites with nanosilver produced a weak inhibitory effect on fibroblasts. The slight decrease in the number of viable fibroblasts observed in MTT assay at higher concentrations of nanosilver was not statistically significant. The counts of viable fibroblasts were similar on all BC/Ag films: $6.95 \cdot 10^{3}$ cells $/ \mathrm{cm}^{2}$ on the BC film with the highest $\mathrm{Ag}$ concentration $(0.01 \mathrm{M}), 7.30 \cdot 10^{3}$ cells $/ \mathrm{cm}^{2}$ on the BC film with an $\mathrm{Ag}$ concentration of $0.001 \mathrm{M}$, and $8.47 \cdot 10^{3}$ cells $/ \mathrm{cm}^{2}$ on the $\mathrm{BC}$ film with the lowest $\mathrm{AgNO}_{3}$ concentration $(0.0001 \mathrm{M})$. These values were comparable with the control $\left(8.85 \cdot 10^{3}\right.$ cells $\left./ \mathrm{cm}^{2}\right)$. Results obtained in the present study are consistent with the published data suggesting that $\mathrm{BC} / \mathrm{AgNps}$ produce a strong inhibitory effect on pathogenic and opportunistic pathogenic microflora, without inhibiting the growth of epidermal cells $[14 ; 61]$.

\section{Conclusion}

New results were obtained on production and properties of bacterial cellulose nanocomposites. Physical, mechanical, and biological properties of $\mathrm{BC} / \mathrm{AgNp}$ and $\mathrm{BC} /$ antibiotic composites synthesized by the hydrothermal method were investigated and compared. The films of bacterial cellulose composites with silver nanoparticles and antibiotics produced in this study were comprehensively investigated, including such parameters as their surface microstructure and properties, temperature characteristics, degree of crystallinity, mechanical properties, the ability of the surface to adsorb proteins, release of nanosilver and antibiotics from composites, antibacterial activity against pathogenic and opportunistic pathogenic microflora, and their effect on epidermal cells. BC composite films were found to have different structure, physicochemical properties and surface characteristics, and their behavior towards pathogenic microflora and fibroblast cell culture differed depending on the type of antibacterial agent contained in them and its concentration in the composite. The disk-diffusion method and the shake-flask culture method used in this study showed that all experimental composites had pronounced antibacterial activity against $E$. coli, $P s$. eruginosa, K. pneumoniae, and St. aureus, and the BC/antibiotic composites were more active than BC/AgNp ones; $S$. aureus was the most susceptible to the effect of BC composites. No potential cytotoxicity was detected in any of the BC/AgNp composites in the NIH 3T3 mouse fibroblast cell culture, in contrast to the BC/antibiotic composites. These results suggest that $\mathrm{BC}$ composites constructed in the present study hold promise as dressings for managing wounds, including contaminated ones.

\section{Acknowledgement}

The study was supported by the RFBR and the Government of the Krasnoyarsk Territory within the framework of Research Project No. 16-43-242024

\section{References}

[1] X. Ma, R.M.Wang, F.M. Guan, T.F.Wang, Artificial dura mater made from bacterial cellulose and polyvinyl alcohol, CN Patent ZL200710015537 (2010).

[2] S. Saska, H.S. Barud, A.M.M. Gaspar, R. Marchetto, S.J.L. Ribeiro, Y. Messaddeq, Bacterial cellulosehydroxyapatite nanocomposites for bone regeneration, Int. J. Biomater., 2011 (2011) 1-8, http://dx.doi.org/10.1155/2011/175362.

[3] W.C. Lin, C.C. Lien, H.J. Yeh, C.M. Yu, S.H. Hsu, Bacterial cellulose and bacterial cellulose chitosan membranes for wound dressing applications, Carbohydr. Polym., 94(1) (2013) 603-611, https://doi.org/10.1016/j.carbpol.2013.01.076.

[4] M. Culebras, C.J. Grande, F.G. Torres, O.P. Troncoso, C.M. Gomez, M.C. Bañó, Optimization of cell growth on bacterial cellulose by adsorption of collagen and poly-L-lysine, Int. J. Polym. Mater. Po., 64(8) (2015) 411-415, http://dx.doi.org/10.1080/00914037.2014.958829.

[5] N. Shah, M. Ul-Islam, W.A. Khattak, J.K.Park, Overview of bacterial cellulose composites: a multipurpose advanced material, Carbohydr. Polym., 98(2) (2013) 1585-1598, https://doi.org/10.1016/j.carbpol.2013.08.018.

[6] H. Kwak, J.E. Kim, J. Go, E.K. Koh, S.H. Song, H.J. Son, H.S. Kim, Y.H.Yun, Y.J. Jung, D.Y. Hwang, Bacterial cellulose membrane produced by Acetobacter sp. A10 for burn wound dressing applications, Carbohydr. Polym., 122 (2015) 387-398, https://doi.org/10.1016/j.carbpol.2014.10.049.

[7] W.S. Chang, H.H. Chen, Physical properties of bacterial cellulose composites for wound dressings, Food Hydrocolloids, 53 (2016) 75-83, https://doi.org/10.1016/j.foodhyd.2014.12.009.

[8] S.L. Percival, P.G. Bowler, D. Russell, Bacterial resistance to silver in wound care, J. Hospit. Infect., 60(1) (2005) 1-7, http://dx.doi.org/10.1016/j.jhin.2004.11.014.

[9] M.L. Dorbe, A. Stoica-Guzum, Antimicrobial Ag-Polyvinyl Alcohol-Bacterial Cellulose Composite Films, J. Biobased Mater. Bioenergy, 7 (2013) 157-162, https://doi.org/10.1166/jbmb.2013.1272.

[10] M. Sureshkumar, D.Y. Siswanto, C.K. Lee, Magnetic antimicrobial nanocomposite based on bacterial cellulose and silver nanoparticles, J. Mater. Chem., 20 (2010) 6948-6955, http://dx.doi.org/10.1039/c0jm00565g.

[11] J. Feng, Q. Shi, W. Li, X. Shu. A. Chen, X. Xie, X. Huang, Antimicrobial activity of silver nanoparticles in situ growth on TEMPO-mediated oxidized bacterial cellulose, Cellulose, 21 (2014) 4557-4567, http://dx.doi.org/10.1007/s10570-014-0449-2. 
[12] G. Yang, J. Xie, Y. Deng, Y. Bian, F. Hong, Hydrothermal synthesis of bacterial cellulose/AgNPs composite: A «green» route for antibacterial application, Carbohydr. Polym., 87(4) (2012) 2482- 2487, https://doi.org/10.1016/j.carbpol.2011.11.017.

[13] X. Wen, Y. Zheng, J. Wu., L. Yue, C. Wang, J. Luan, Z. Wu, K. Wang, In vitro and in vivo investigation of bacterial cellulose dressing containing uniform silver sulfadiazine nanoparticles for burn wound healing, Progress in Natural Science: Materials International, 25 (2015) 197-203, https://doi.org/10.1016/j.pnsc.2015.05.004.

[14] J. Wu, Y. Zheng, W. Song, J. Luan, X. Wen, Z. Wu, X. Chen, Q. Wang, S. Guo, In situ synthesis of silvernanoparticles/bacterial cellulose compositesfor slow-released antimicrobial wound dressing, Carbohydr. Polym., 102 (2014) 762-771, https://doi.org/10.1016/j.carbpol.2013.10.093.

[15] V. Sadanand, H. Tian, A.Varada Rajulu, B. Satyanarayana, Antibacterial cotton fabric with in situ generated silver nanoparticles by one-step hydrothermal method, Int. J. Polym. Anal. Charact., 22(3) (2017) 275-279, http://dx.doi.org/10.1080/1023666X.2017.1287828.

[16] V. Sadanand, T.H. Feng, A.Varada Rajulu, B. Satyanarayana, Preparation and properties of low-cost cotton nanocomposite fabrics with in situ-generated copper nanoparticles by simple hydrothermal method, Int. J. Polym. Anal. Charact., (2017) 1-8, http://dx.doi.org/10.1080/1023666X.2017.1344916.

[17] V. Sadanand, N. Rajini, B. Satyanarayana, A.Varada Rajulu, Preparation and properties of cellulose/silver nanoparticle composites with in situ-generated silver nanoparticles using Ocimum sanctum leaf extract, Int. J. Polym. Anal. Charact., 21(5) (2016) 408-416, http://dx.doi.org/10.1080/1023666X.2016.1161100.

[18] P. Sivaranjana, E.R. Nagarajan, N. Rajini, M. Jawaid, A. Varada Rajulu, Cellulose nanocomposite films with in situ generated silver nanoparticles using Cassia alata leaf extract as a reducing agent, Int. J. Biol. Macromol., 99 (2017) 223-232, https://doi.org/10.1016/j.ijbiomac.2017.02.070.

[19] L. Muthulakshmi, N. Rajini, H. Nellaiah, T. Kathiresan, M. Jawaid, A.V. Rajulu, Preparation and properties of cellulose nanocomposite films with in situ generated copper nanoparticles using Terminalia catappa leaf extract, Int. J. Biol. Macromol., 95 (2017) 1064-1071, http://dx.doi.org/10.1016/j.ijbiomac.2016.09.114 0141.

[20] L. Muthulakshmi, N. Rajini, H. Nellaiah, T. Kathiresan, M. Jawaid, A.V. Rajulu, Experimental Investigation of Cellulose/Silver Nanocomposites Using In Situ Generation Method, J. Polym. Environ., 24 (2016), http://dx.doi.org/10.1007/s10924-016-0871-7

[21] M. Khalil, J. Yu, N. Liu, R.L. Lee, Hydrothermal synthesis, characterization, and growth mechanism of hematite nanoparticles, J. Nanopart. Res., 16 (2014) 2362, http://dx.doi.org/10.1007/s11051-014-2362-x.

[22] R. Xiong, C. Lu, Y. Wang, Z. Zhou, X. Zhang, Nanofibrillated cellulose as the support and reductant for the facile synthesis of Fe3O4/Ag nanocomposites with catalytic and antibacterial activity, J. Mater. Chem. A, 47 (2013) 14910-14918, http://dx.doi.org/10.1039/c3ta13314a

[23] R. Xiong, C. Lu, W. Zhang, Z. Zhou, X, Zhang, Facile synthesis of tunable silver nanostructures for antibacterial application using cellulose nanocrystals, Carbohydr. Polym., 95 (2013) 214-219, http://dx.doi.org/10.1016/j.carbpol.2013.02.077.

[24] H. Yu, B. Sun, D. Zhang, G. Chen, X. Yanga, J. Yao, Reinforcement of biodegradable poly(3-hydroxybutyrateco-3-hydroxyvalerate) with cellulose nanocrystal/silver nanohybrids as bifunctional nanofillers, J. Mater. Chem. B, 48 (2014) 8479-8489, http://dx.doi.org/10.1039/C4TB01372G.

[25] H.-Y. Yu, X.-Y. Yang, F.-F. Lu, G.-Y. Chen, J.-M. Yao, Fabrication of multifunctional cellulose nanocrystals/poly(lactic acid)nanocomposites with silver nanoparticles by spraying method, Carbohydr. Polym., 140 (2016) 209-219, http://dx.doi.org/10.1016/j.carbpol.2015.12.030.

[26] W. Xu, Z. Qin, H. Yu, Y. Liu, N. Liu, Z. Zhou, L. Chen, Cellulose nanocrystals as organic nanofillers for transparent polycarbonate films, J. Nanopart. Res., 15 (2013) 1562-1570, http://dx.doi.org/10.1007/s11051-0131562-0.

[27] Y. Han, X. Wu, X. Zhang, Z. Zhou, C. Lu, Reductant-Free Synthesis of Silver Nanoparticles-Doped Cellulose Microgels for Catalyzing and Product Separation, ACS Sustainable Chem. Eng., 4(12) (2016) 6322-6331, http://dx.doi.org/10.1021/acssuschemeng.6b00889

[28] B. Wei, G. Yang, F. Hong, Preparation and evaluation of a kind of bacterial cellulose dry films with antibacterial properties, Carbohydr. Polym., 84(1) (2011) 533-538, https://doi.org/10.1016/j.carbpol.2010.12.017.

[29] W. Shao, H. Liu, S. Wang, J. Wu, M. Huang, H. Min, X. Liu, Controlled release and antibacterial activity of tetracyclinehydrochloride-loaded bacterial cellulose composite membranes, Carbohydr. Polym., 145 (2016) 114120, https://doi.org/10.1016/j.carbpol.2016.02.065.

[30] C.J.Wijaya, S.N. Saputra, F.E. Soetaredjo, J.N. Putro, C.X. Lin, A. Kurniawan, Y.H. Ju, S. Ismadji, Cellulose nanocrystals from passion fruit peels waste as antibiotic drug carrier, Carbohydr. Polym., 175 (2017) 370-376, https://doi.org/10.1016/j.carbpol.2017.08.004

[31] S. Hestrin, M. Schramm, Synthesis of cellulose by Acetobacter xylinum. 2. Preparation of freeze-dried cells capable of polymerizing glucose to cellulose. Biochem. J., 58(2) (1954) 345-352.

[32] S.V. Prudnikova, T.G. Volova, E.I. Shishatskaya, Shtamm bakterii Komagataeibacter xylinus - produtsent bakterialnoi tsellulozy (A strain of bacterium Komagataeibacter xylinus - a producer of bacterial cellulose. RF Patent for an invention No. 2568605. Priority of 11 December 2014. Registered in the RF State Register on 27 October 2015 (in Russian). 
[33] S.V. Prudnikova, I. P. Shidlovsky, The New Strain of Acetic Acid Bacteria Komagataeibacter xylinus B-12068 - Producer of Bacterial Cellulose for Biomedical Applications, SibFU Journal. Biology, 10(2) (2017) 246-254, https://doi.org/10.17516/1997-1389-0017.

[34] G. Yang, J. Xie, Y. Deng, Y. Bian, F. Hong, Hydrothermal synthesis of bacterial cellulose/AgNPs composite: A «green» route for antibacterial application, Carbohydr. Polym., 87(4) (2012) 2482- 2487, https://doi.org/10.1016/j.carbpol.2011.11.017.

[35] D.K. Owens, R.C. Wendt, Estimation of the surface free energy of polymers, J. Appl. Polym. Sci., 13 (1969) 1741-1747, https://doi.org/10.1002/app.1969.070130815

[36] D.H. Kaelble, Dispersion-polar surface tension properties of organic solids, J. Adhes. 2 (1970) 66-81, https://doi.org/10.1080/0021846708544582

[37] R. Jung, Y. Kim, H. S. Kim, H.J. Jin, Antimicrobial Properties of Hydrated Cellulose Membranes With Silver Nanoparticles, J. Biomater. Sci.-Polym. Ed., 20(3) (2009) 311-324, https://doi.org/10.1163/156856209X412182

[38] T. Maneerung, S. Tokura, R. Rujiravanit, Impregnation of silver nanoparticles into bacterial cellulose for antimicrobial wound dressing, Carbohydr. Polym., 72(1) (2008) 43-51, https://doi.org/10.1016/j.carbpol.2007.07.025

[39] H.G.O. Barud, R. R. Silva, H. Silva Barud, A. Tercjak, J. Gutierrez, W. R. Lustri, O.B. Oliveira Junior, S.J.L. Ribeiro, A multipurpose natural and renewable polymer in medical applications: Bacterial cellulose, Carbohyd. Polym., 153 (2016) 406-420, https://doi.org/10.1016/j.carbpol.2016.07.059.

[40] A.D. French, Idealized powder diffraction patterns for cellulose polymorphs, Cellulose, 21(2) (2014) 885-896, https://doi.org/10.1007/s10570-013-0030-4.

[41] F. Mohammadkazemi, M. Azin, A. Ashori, Production of bacterial cellulose using different carbon sources and culture media, Carbohydr. Polym., 117 (2015) 518-523, https://doi.org/10.1016/j.carbpol.2014.10.008.

[42] C. Huang, H. J. Guo, L. Xiong, B. Wang, S.L. Shi, X.F. Chen, X.Q. Lin, C. Wang, J. Luo, X.D. Chen, Using wastewater after lipid fermentation as substrate for bacterial cellulose production by Gluconacetobacter xylinus, Carbohydr. Polym., 136 (2016) 198-202, https://doi.org/10.1016/j.carbpol.2015.09.043

[43] W. Shao, H. Liu, X. Liu, H. Sun, S. Wang, R. Zhang, pH-responsive release behavior and anti-bacterial activity of bacterialcellulose-silver nanocomposites, Int. J. Biol. Macromol., $76 \quad$ (2015) 209-217, https://doi.org/10.1016/j.ijbiomac.2015.02.048.

[44] Z. Yan, S. Chen, H. Wang, B. Wang, J. Jiang, Biosynthesis of bacterialcellulose/multi-walled carbon nanotubes in agitated culture. Carbohydr. Polym., 74 (2008), 659-665, https://doi.org/10.3390/ma9030183.

[45] Y. Zhang, H. Peng, W. Huang, Y. Zhou, D. Yan, Facile preparation and characterization of highly antimicrobial colloid $\mathrm{Ag}$ or $\mathrm{Au}$ nanoparticles, J. Colloid Interface Sci., 325 (2008), 371-376, https://doi.org/10.1016/j.jcis.2008.05.063.

[46] H.S. Barud, C.A. Ribeiro, M.S. Crespi, M.A.U. Martines, J. Dexpert-Ghys, R.F.C. Marques, S.J.L. Ribeiro, Thermal characterization of bacterial cellulose-phosphate composite membranes. J. Therm. Anal. Calorim., 87(3) (2007) 815-818, https://doi.org/10.1007/s10973-006-8170-5

[47] A. Vazquez, M.L. Foresti, P. Cerrutti, M. Galvagno, Bacterial cellulose from simple and low cost production media by Gluconacetobacter xylinus. J. Polym. Environ., 21(2) (2013) 545-554, https://doi.org/10.1007/s10924012-0541-3

[48] B. Surma-Ślusarska, S. Presler, D. Danielewicz, Characteristics of bacterial cellulose obtained from Acetobacter xylinum culture for application in papermaking. FTEE, 4 (69) (2008) 108-111, https://doi.org/10.21833/ijaas.2017.03.004.

[49] Y. Feng, X. Zhang, Y. Shen, K. Yoshino, W. Feng, A mechanically strong, flexible and conductive film based on bacterial cellulose/graphene nanocomposite, Carbohydr. Polym. 87(1) (2012) 644-649, https://doi.org/10.1016/j.carbpol.2011.08.039.

[50] A. Yoshino, M. Tabuchi, M. Uo, H. Tatsumi, K. Hideshima, S. Kondo, J. Sekine, Applicability of bacterial cellulose as an alternative to paper points in endodontic treatment. Acta Biomater., 9(4) (2013), 6116-6122, https://doi.org/10.1016/j.actbio.2012.12.022.

[51] Y.Wan, D. Hu, G. Xiong, D. Li, R. Guo, H. Luo, Directional fluid induced self-assembly of oriented bacterial cellulose nanofibers for potential biomimetic tissue engineering scaffolds, Mater. Chem. Phys., 145 (2015) 7-11, https://doi.org/10.1016/j.matchemphys.2014.10.037.

[52] V. Sadanand, N. Rajini, A.V. Rajulu, B. Satyanarayana, Preparation of cellulose composites with in situ generated copper nanoparticles using leaf extract and their properties, Carbohydr. Polym., 150 (2016) 32-39, http://dx.doi.org/10.1016/j.carbpol.2016.04.121.

[53] B. Jia, Y. Mei, L. Cheng, J. Zhou, L. Zhang, Preparation of copper nanoparticles coated cellulose films with antibacterial properties through one-step reduction, ACS Appl. Mater. Interfaces, 4(6) (2012) 2897-2902, http://dx.doi.org/10.1021/am3007609.

[54] L. Long, X. Yuan, Z. Li, K. Li, Z. Cui, X. Zhang, J. Sheng, Anti-fouling properties of polylactic acid film modified by pegylated phosphorylcholine derivatives, Mater. Chem. Phys. 143 (2014) 929-938, http://dx.doi.org/10.1016/j.matchemphys.2013.09.041.

[55] B.L. Wang, Z. Ye, Y. Tang, H. Liu, Q. Lin, H. Chen, K. Nan, Loading of antibiotics into polyelectrolyte multilayers after self-assembly and tunable release by catechol reaction, J. Phys. Chem. C, 120 (2016) 6145-6155, http://dx.doi.org/10.1021/acs.jpcc.6b00957. 
[56] B.L. Wang, T.W. Jin, Y.M. Han, C.H. Shen, Q. Li, Q. K. Lin, H. Chen. Bio-inspired terpolymers containing dopamine, cations and MPC: a versatile platform to construct a recycle antibacterial and antifouling surface, J. Mater. Chem., 3 (2015) 5501-5510, http://dx.doi.org/10.1039/C5TB00597C.

[57] S. Dominguez-Medina, J. Blankenburg, J. Olson, C.F. Landes, S. Link, Adsorption of a Protein Monolayer via Hydrophobic Interactions Prevents Nanoparticle Aggregation under Harsh Environmental Conditions, ACS Sustain Chem. Eng., 1(7) (2013) 833-842, http://dx.doi.org/10.1021/sc400042h.

[58] X. Xu, T. Jin, B. Zhang, H. Liu, Z. Ye, Q. Xu, H. Chen, B. Wang, In vitro and in vivo evaluation of the antibacterial properties of a nisingrafted hydrated mucin multilayer film, Polym. Test. 57 (2017) 270-280, https://doi.org/10.1016/j.polymertesting.2016.12.006.

[59] J.P. Ruparelia, Strain specificity in antimicrobial activity of silver and copper nanoparticles, Acta Biomater. 4(3) (2008) 707-716, https://doi.org/10.1016/j.actbio.2007.11.006.

[60] S.H. Barud, T. Regiani, R.F.C. Marques, W.R.Lustry, Y. Messaddeq, S.J.L. Ribeiro, Antimicrobial Bacterial Cellulose-Silver Nanoparticles Composite Membranes, J. Nanomater., $2011 \quad$ (2011) 1-8, http://dx.doi.org/10.1155/2011/721631.

[61] J. Zhang, P. Chang, C. Zhang, G. Xiong, H. Lio, Y. Zhu, K. Ren, F. Yao, Y. Wan, Immobilization of lecithin on bacterial cellulose nanofibers for improved biological functions, React. Funct. Polym., 91 (2015) 100-107, https://doi.org/10.1016/j.reactfunctpolym.2015.05.001. 